\title{
Investigations of powder reusing on microstructure and mechanical properties of Inconel 718 obtained by additive manufacturing
}

Elie Paccou ${ }^{1}$, Morgane Mokhtari ${ }^{1,2,}$ Clément Keller ${ }^{1,2^{\star}}$, Josiane Nguejio ${ }^{1}$, Williams Lefebvre ${ }^{1}$, Xavier Sauvage ${ }^{1}$, S. Boileau ${ }^{3}$, P. Babillot ${ }^{3}$, Pierre Bernard ${ }^{4}$, Eric Bauster ${ }^{5}$

${ }^{1}$ Groupe de Physique des Matériaux, CNRS-UMR 6634, Université de Rouen, INSA de Rouen, Avenue de I 'Université, 76800 Saint-Etienne du Rouvray, France

${ }^{2}$ Laboratoire de Génie de Production, Ecole Nationale d'Ingénieurs de Tarbes, 65000 Tarbes, France

${ }^{3}$ Laboratoire Analyses et surface, Groupe 6napse, 2 voie de l'innovation 27100 Val De Reuil

${ }^{4}$ ArianeGroup, Forêt de Vernon, 27200, Vernon, France

${ }^{5}$ Volum-e, Rue de la fonderie, 76340, Blangy-sur-bresle, France

* corresponding author: clement.keller@enit.fr, +33562442721

Keywords : Nickel Based Superalloy, Additive manufacturing, Reusability, Mechanical Properties, Microstructure

\section{Abstract}

Laser powder bed fusion, largely employed for additive manufacturing, induces after each batch a large quantity of remaining powder. This study focuses on the possibility to reuse this remaining powder after a large number of production cycles and on the influence of such reusing on the microstructure and mechanical properties. Inconel 718 parts made from fresh and 50 times reused powder were processed and then characterized in the asbuilt state. The effect of powder reuse on the microstructure was assessed thanks to a multiscale study and the resulting mechanical response was evaluated using both monotonous and cyclic tests. Our results clearly show that despite a better powder flowability for the reused powder, only minor differences between the two investigated materials demonstrating the possibility of high-quality parts production from reused powders. 


\section{Introduction}

In the last decades, the ability of complex parts production directly from a computer aided design without machining or assembling step has increased the interests in Additive Manufacturing (AM) [1-4]. Among all AM techniques, Laser Powder Bed Fusion (LBPF) also called Selective Laser Melting (SLM) is the most common technique due to its high capability to build complex parts with generally improved mechanical properties [2-7]. This layer-by-layer process is however known to induce some defects such as porosities, inclusion of unmelt powder, residual stress $[8,9]$ and also non-equiaxed grain growth. This later phenomenon typically gives rise to anisotropic mechanical behavior [10-12].

For cost limitation and sustainable development, one challenge of powder bed fusion processes is the direct reusing of unmelt powders collected after each completed batch. A first possibility is to mix fresh powder (feedstock) and reused powder together, which is called refreshment. Another approach is to use the entire powder feedstock by, for instance, the production of smaller and smaller parts while the amount of powder is decreasing or to mix reused powder from different fabrication lots [13]. Although reused powder does not participate directly to the fabrication, it is affected by the process. Reused powders typically exhibit different particle size distributions as compared to fresh powders [14]. Particles can agglomerate resulting in large particles that do not melt completely during the process and thus leading to defected zones. Such large particles can be easily removed by a sieving process. However, even so, the average particle size tends to increase and particles may exhibit so-called "satellites" whereas their sphericity decreases. All these features typically lead to a diminution in the tape density and thus in the density of the final product [14-17]. The effect of reusing is not limited to the particle morphology but it can also affect the powder composition. For instance, spatters are created from powder or molten material ejected from the melt pool during the laser scanning. When spatters eject from the powder bed, they may have been partially or fully melted and solidified in the chamber environment [18].

Thus, an increase in oxygen amount is sometimes reported [15,19-21]. Based on the relationship between tape and final density, a 5 steps method has been proposed to check if reused powders are suitable for fabrication [13]. In this method, the main parameters are particle size distribution, shape factor, oxygen content, flowability and tape density [13]. In the specific case of steels, a particle magnetic separation in addition to sieving has been proposed [15]. In this later case, filters stream could be tuned to separate particles into 
three categories: non-magnetic (oxides), weakly magnetic (reusable powder), and highly magnetic $\left(\mathrm{Fe}_{3} \mathrm{O}_{4}\right.$, spatter with high ferrite content) [15] which can help maintaining the quality of the feedstock.

When it comes to mechanical properties, only few studies focused on the powder reusing influence have been published. These studies are mainly dedicated to AISiMg alloys [22,23], Ti-6Al-4V [21,24-26], 316L stainless steel [15,27] and Inconel 718 (IN718) [14,19]. For AISiMg alloys, a single powder reuse (with sieving process) does not modify the mechanical properties [22]. However, after 8 reuses (with sieving process and heat treatment on parts) a 4\% decrease on ultimate tensile strength (UTS) and yield stress were reported [23]. Concerning as-built Ti-6Al-4V, parts porosity decreases (from $0.1 \%$ to $0.05 \%$ ) after 12 reuses (with sieving and refreshment) whereas a slight increase in surface roughness, hardness and UTS (4-7\%) were reported [26]. For the same material, other studies involving samples manufactured after 21 and 37 reuses (with sieving and mixing with the feedstock) confirmed the slight increases in UTS and in yield strength with powder reuse due to an increase in oxygen and nitrogen concentration $[21,25]$. In case of heattreated Ti-6Al-4V samples manufactured from new and 15 time reused powder [24], it was shown that no increase in UTS related to the powder reuse was noticed. Nevertheless, the fatigue life at high cycle regime of machined samples from reused powders shows a significantly larger number of cycles to failure $\left(10^{7}\right.$ vs $\left.10^{6}\right)$. Regarding machined $316 \mathrm{~L}$ stainless steel, it was shown that the use of powders contaminated by spatters highly decrease the mechanical properties ( $-25 \%$ on UTS and elongation break divided by 2) [27]. However, even after 30 powder reuses (with sieving), it was reported a slight decrease in part density and a light ductility increase whereas UTS and yield stress remain relatively constant [15]. For IN718, after 14 reuses of powder (with sieving and mixing with the feedstock), both microstructure (including porosity) and mechanically properties (toughness) are similar for as-built samples [14]. This result was confirmed by another study where 9 reuses (with sieving) do not induce any significant difference in tensile and low fatigue properties [19].

Thus, due to the large number of parameters controlling the LPBF process and the large number of potential reusing cycles, there is still a lack of understanding of the influence of powder reusing on final microstructures and the resulting properties. It should be emphasized that it requires a deep multiscale investigation of microstructures combined with a systematic evaluation of the mechanical behavior. Besides, in the case of age 
hardening alloys, post-processing aging treatments could bring, additionally, another level of complexity.

In the present work, the LPBF method has been applied to IN718 alloy. This precipitation hardening Ni-based superalloy is widely used as structural components due to its high mechanical properties at high-temperature and under corrosive environment [28]. Due to its good weldability, IN718 can be produced by LPBF resulting in parts exhibiting almost nearly no pores and excellent mechanical properties $[9,28-30]$.

In the specific case of the IN718, of great industrial interest, the influence of high number powder reusing has not been explored and no definitive conclusions can be drawn about the effect of this powder reusing. Moreover, to the best author's knowledge, very few coupled investigations of powder reusing, microstructure and mechanical properties characterization have been reported. This lack of knowledge is detrimental to the elaboration of a criteria that can be industrially employed to predict the maximal number of part production with a given feedstock.

The objective of this work is, then, to investigate the evolution of the microstructure (by scanning and transmission electron microscopy, and also atom probe tomography) and mechanical properties (monotonous tensile tests and cyclic tests) for IN718 parts, in the as-built state, manufactured by laser powder bed fusion after 1 and 51 manufacturing cycles. This microstructure and mechanical behavior assessment is then compared to the powder characteristics. As small variations of chemical elements such as $\mathrm{Al}, \mathrm{Ti}$ or $\mathrm{Nb}$ from one powder to another may alter, after ageing, the strengthening related to the gamma' and gamma" precipitates formation [31,32], the as-built state has been considered for this study to keep those elements mainly in solid solution. Results revealed that both microstructure and mechanical properties are not significantly affected by such a large number of powder reusing cycles. 


\section{Materials and methods}

\section{II.1. Materials and process}

The IN718 powder used in this study was produced by gas atomization by Aubert \& Duval. The sample manufacturing has been performed by laser powder bed fusion on an EOS M400 machine in Volum-e company under protective Ar atmosphere with 4 lasers. Figure 1 illustrates the build layout for each powder type. Table 1 summarizes the parameters set employed for the AM process.

To investigate the influence of powder reusing on the microstructure and mechanical properties, two series of samples were manufactured, a first one exclusively with fresh powder (named R0) and a second one with a powder (of the same initial batch) used for a total of 50 printing jobs (named R50). Regarding powder reuse, so far, no international standards have published to define a reliable and efficient strategy. In this investigation, the powder reusing procedure consists in a sieving step of the remaining powder to remove particles with diameter higher than $63 \mu \mathrm{m}$ close to the D90 of the initial size distribution. During this sieving step the powder is exposed to an argon atmosphere to reduce powder oxidation. This procedure is based on the Volum-e company knowledge and also followed the international ISO/ASTL 52907 and ECSS-Q-ST-70-80C (from European Space Agency) recommendations. Between these two specific layouts, general industrial products were produced. These jobs were characterized by a similar volume of melted powder compared to the R1 and R50 layouts. 


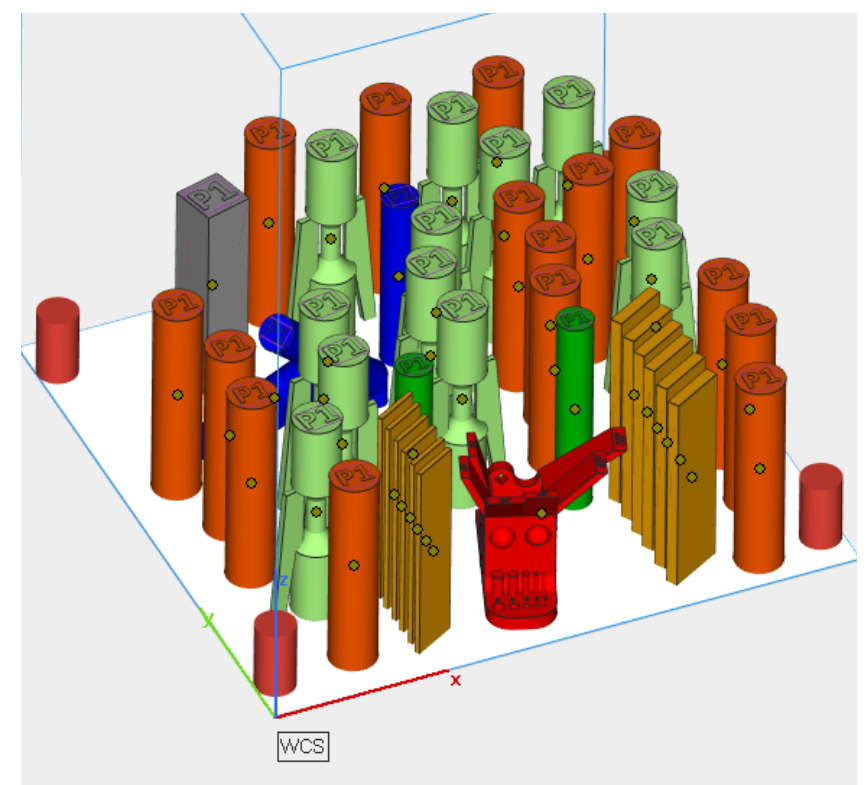

Figure 1: Illustration of the build layout for the manufacturing of the samples printed with new (R0) or reused powder (R50). Note that only the orange colored samples have been considered in the present study.

Table 1 : LPBF manufacturing parameters employed in this study

\begin{tabular}{|c|c|c|c|c|}
\hline $\begin{array}{c}\text { Laser power } \\
(\mathrm{W})\end{array}$ & $\begin{array}{c}\text { Laser scanning } \\
\text { speed }(\mathrm{mm} / \mathrm{s})\end{array}$ & $\begin{array}{c}\text { Powder layer } \\
\text { thickness }(\mu \mathrm{m})\end{array}$ & $\begin{array}{c}\text { Hatch distance } \\
(\mathrm{mm})\end{array}$ & $\begin{array}{c}\text { Scanning } \\
\text { rotation }\end{array}$ \\
\hline 400 & 1330 & 40 & 0.1 & $67^{\circ}$ \\
\hline
\end{tabular}

\section{II.2. Methods}

Powder

For chemical composition analysis of the two powders, Inductively Coupled Plasma (ICP) has been employed. The particle size distribution has been also characterized for both powder using a MASTERSIZER 2000 laser granulometry measurement device working in liquid dispersion. Together with this particle size distribution of the powder, their conventional flow rate through Hall flowmeter funnel (ASTM B213) have been assessed. Apparent density has been measured with the same Hall flowmeter (ASTM B212) and tap density was measured with a Densitap machine following ASTM B 527 standard. For a better characterization of the powder flowability, Parameters such as avalanche energy, break energy, avalanche and rest angles has been measured with a rotative drum device (Mercury scientific).

\section{Microstructure}

Samples were extracted from as build parts to perform microstructure analyses. Scanning Electron Microscopy (SEM) observations were performed with a JEOL 7900F equipped with an Electron Back-Scattered Detector (EBSD) and an Energy Dispersed X-Ray 
Spectroscopy (EDS) detectors. For EBSD, sample surfaces were electrolytically polished with a $9 \%$ water, $10 \%$ glycol, $8 \%$ perchloric acid and $73 \%$ ethanol solution at room temperature at $20 \mathrm{~V}$.

For porosity observations, samples were mounted in epoxy castings and polished with SiC abrasive papers, following by a mechanical polishing with diamond suspensions down to 1 $\mu \mathrm{m}$. SEM images were taken on the horizontal $(X Y)$ as well as on vertical $(X Z)$ sections of each sample, and surface pictures are recorded in areas where the pores density is important. ImageJ software was used to analyze the $X Y$ and $X Z$ images by using a thresholding feature to highlight pores. Then, area and fit ellipse parameters were recorded using the "Analyze Particles" function. An average value is estimated based on the analysis of six images.

Foils for Transmission Electron Microscopy (TEM) investigations were prepared by grinding coupons down to approximately $80 \mu \mathrm{m}$ and then punched to obtain disks with a diameter of $3 \mathrm{~mm}$. Those disks were electropolished with a 10\% perchloric acid solution in $90 \%$ methanol at $-35^{\circ} \mathrm{C}$ and $20 \mathrm{~V}$ using a twin-jet Tenupol-5 to obtain electron transparency.

Atom probe analyses were performed on as-printed microstructure using a Cameca LEAP $4000 \mathrm{HR}$. Field evaporation was carried out with electric pulses (20\% pulse fraction and $200 \mathrm{kHz}$ pulse repetition rate) with a sample temperature of $70 \mathrm{~K}$ that allows the quantitative measurement of phase compositions in IN718. Samples were prepared by Focused Ion Beam (FIB) using a Thermofisher Plasma FIB Helios (Xe ions). The three-dimensional reconstruction procedure and data analysis were conducted with the IVAS software package. For each investigated state, at least $2.10^{6}$ ions were analyzed which is considered sufficiently representative for bulk composition analysis.

\section{Mechanical tests}

To characterize the influence of the powder reusing on the mechanical properties, monotonic and cyclic tests were carried out. To this aim, as-built cylinders of $90 \mathrm{~mm}$ height and $26 \mathrm{~mm}$ diameter were machined to obtain conventional dog-bone specimens with a gage section of $20 \mathrm{~mm}$ height and $8 \mathrm{~mm}$ diameter following the ISO-12106:2017 standard. All tests were performed with a strain rate of about $(2.2 \pm 0.5) \cdot 10^{-3} \mathrm{~s}^{-1}$ with an axial strain measurement carried out by a "clip-on" extensometer. Monotonic mechanical behavior was assessed with tensile tests up to fracture on an electromechanical MTS C45 tensile machine with a cross-head displacement control mode. Cyclic mechanical behavior was examined with Cyclic Stress-Strain Curves (CSSC) and fatigue tests on a MTS servo- 
hydraulic machine with a load capacity of $100 \mathrm{kN}$ with a total strain amplitude control. Both tests were carried out with a symmetric tensile/compression loading ( $R=-1)$. CSSC were employed to quickly identify the cyclic behavior of each material over a wide region of plastic strain amplitudes. These tests were performed with an increase in the total strain amplitude from $10^{-4}$ to $10^{-1}$ every 250 cycles. After 250 cycles, the evolution of stress and strain amplitude and mean stress and strain were assessed. Stress amplitude, mean stress and plastic deformation values given in the results part, corresponds to an average of the 5 last cycles of each total strain amplitude. Based on these first cyclic tests, 3 different total strain amplitudes were chosen to perform pure fatigue tests: $2.7510^{-3}, 4.25$ $10^{-3}$ and $7.510^{-3}$. These three amplitudes are expected to correspond to high-cycle fatigue, intermediate and low-cycle fatigue domain, respectively. At least 3 samples were employed for each mechanical test (tensile, CSSC and fatigue) for both new or reused powders.

\section{Results and discussion}

\section{1 Powders and fused materials chemical composition}

Composition for powders and manufactured samples are displayed in Table 2. Oxygen content of the reused powder is about $85 \%$ higher than the new powder. This increase is impinged to the interaction of powder with atmosphere during the reusing process. However, even if the sample manufactured from fused reused powder still exhibits a $45 \%$ higher oxygen content than the one built with fresh powder, one should notice that the increase is reduced for manufactured samples compare to powders. This feature suggests that the oxygen of the powder is not entirely translated into the solid material. Moreover, in all cases (fresh and reused powders and related manufactured samples), the oxygen content still fulfills the requirements of the aeronautic qualified procedure for industrial use of this material. 
Table 2 : Chemical composition obtained by ICP of IN718 powders (new and reused) and manufactured samples (from new and reused powder) used in this study.

\begin{tabular}{|c|c|c|c|c|c|c|c|c|c|c|c|c|c|c|}
\hline & & $\mathrm{Ni}$ & $\mathrm{Cr}$ & $\mathrm{Fe}$ & $\mathrm{Nb}$ & Mo & $\mathrm{Ti}$ & Al & C & 0 & Si & Co & $\mathbf{N}$ & H \\
\hline \multirow{2}{*}{ At $\%$} & New powder & 52.38 & 21.35 & 18.2 & 3.36 & 1.86 & 1.33 & 1.18 & 0.14 & 0.054 & 0.06 & 0.02 & 0.04 & 0.017 \\
\hline & Reused powder & 52.33 & 21.08 & 18.59 & 3.23 & 1.86 & 1.22 & 1.12 & 0.19 & 0.1 & 0.1 & 0.05 & 0.04 & 0.035 \\
\hline \multicolumn{2}{|c|}{ Uncertainty (\%) } & \pm 1.45 & \pm 0.65 & \pm 0.52 & \pm 0.1 & \pm 0.06 & \pm 0.04 & $\begin{array}{l} \pm 0.0 \\
6\end{array}$ & \pm 0.05 & \pm 0.004 & \pm 0.02 & $\begin{array}{l} \pm 0.0 \\
1\end{array}$ & \pm 0.04 & $\mathrm{n} / \mathrm{a}$ \\
\hline \multirow{2}{*}{ At $\%$} & $\begin{array}{l}\text { Sample from } \\
\text { new powder }\end{array}$ & 52.515 & 21.198 & $\begin{array}{l}18.17 \\
8 \\
\end{array}$ & $\begin{array}{l}3.41 \\
5 \\
\end{array}$ & 1.887 & 1.333 & $\begin{array}{l}1.16 \\
1 \\
\end{array}$ & $\begin{array}{l}0.14 \\
5 \\
\end{array}$ & 0.04 & 0.041 & 0.01 & $\begin{array}{l}0.04 \\
1 \\
\end{array}$ & 0.004 \\
\hline & $\begin{array}{l}\text { Sample from } \\
\text { reused powder }\end{array}$ & 52.492 & 21.149 & $\begin{array}{l}18.51 \\
9 \\
\end{array}$ & 3.19 & 1.876 & 1.16 & $\begin{array}{l}1.09 \\
4 \\
\end{array}$ & $\begin{array}{l}0.19 \\
3 \\
\end{array}$ & 0.058 & 0.082 & $\begin{array}{l}0.06 \\
9 \\
\end{array}$ & $\begin{array}{l}0.05 \\
6 \\
\end{array}$ & 0.009 \\
\hline \multicolumn{2}{|c|}{ Uncertainty (\%) } & \pm 0.45 & \pm 0.34 & \pm 0.25 & $\begin{array}{l} \pm 0.0 \\
6 \\
\end{array}$ & \pm 0.04 & \pm 0.05 & $\begin{array}{l} \pm 0.0 \\
7 \\
\end{array}$ & \pm 0.05 & \pm 0.04 & \pm 0.02 & $\begin{array}{l} \pm 0.0 \\
1 \\
\end{array}$ & \pm 0 . & \\
\hline
\end{tabular}

\section{2 Powder characterization}

For the fresh powder, laser diffraction inspection of the fresh powder indicates that $10 \%$ of the powder exhibits a particle size below $14.6 \mu \mathrm{m}$ (D10), 50\% below $27.1 \mu \mathrm{m}$ (D50) and 90\% below $49.0 \mu \mathrm{m}$ (D90). For the reused powder, the particle size distribution is modified with: D10=19.2 $\mu \mathrm{m}, \mathrm{D} 50=30.8 \mu \mathrm{m}$ and D90=49.6 $\mu \mathrm{m}$ showing an average particle size increase slightly larger than the ones reported in literature [14,33,34]. This modification of the particle size distribution is also depicted in figure 2(a) with a translation of the distribution towards larger values for the reused powder. This phenomenon is due to the presence of spatters and satellites which increase the particle size for the R50 powder and reduce its circularity as illustrated on the circularity distribution of the powder particles (see figure 2(b)). This slight particle size increase may results in an increment of the surface roughness for netshape samples [33].
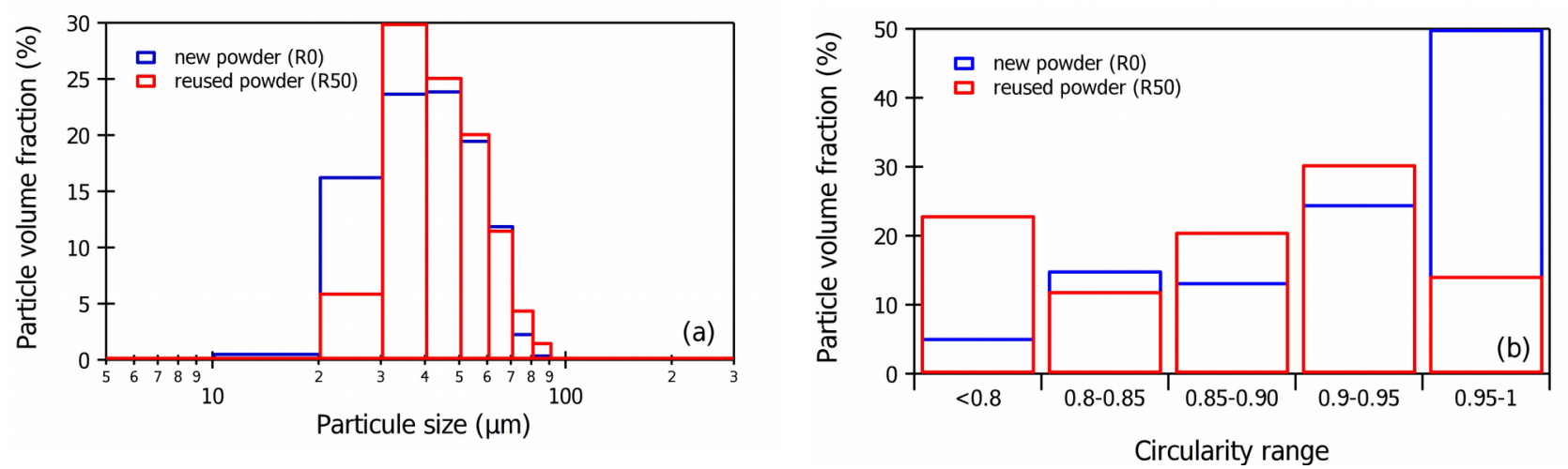

Figure 2: (a) Size distribution of powder particles for the new and reused powder with their corresponding circularity distribution in (b). 
The powder characteristics, i.e., flowrate with Hall funnel, apparent and tap density as well as avalanche energy, break energy, avalanche and rest angles (see tab. 3).

Table 3 : Summary of the powder characteristics for the new (R0) and reused (R50) powders.

\begin{tabular}{|c|c|c|c|c|c|c|c|}
\hline Powder & $\begin{array}{c}\text { Flowability } \\
\text { (Hall Funnel) } \\
\text { (s) }\end{array}$ & $\begin{array}{c}\text { Tap } \\
\text { density }\end{array}$ & $\begin{array}{c}\text { Apparent } \\
\text { density }\end{array}$ & $\begin{array}{c}\text { Avalanche } \\
\text { energy } \\
\text { (mJ/kg) }\end{array}$ & $\begin{array}{c}\text { Break energy } \\
\text { (mJ/kg) }\end{array}$ & $\begin{array}{c}\text { Avalanche } \\
\text { angle } \mathbf{(}^{\circ}\end{array}$ & $\begin{array}{c}\text { Rest } \\
\text { angle } \\
\left({ }^{\circ}\right)\end{array}$ \\
\hline $\begin{array}{c}\text { New } \\
\text { (R0) }\end{array}$ & n.a. & 5.26 & 4.50 & 22.11 & 29.34 & 51.79 & 32.51 \\
\hline $\begin{array}{c}\text { Reused } \\
\text { (R50) }\end{array}$ & 16.16 & 5.12 & 4.35 & 11.91 & 16.62 & 44.26 & 31.84 \\
\hline
\end{tabular}

The comparison of the two powder characteristics clearly illustrates an increase in flowability for the reused powder whereas the tap and apparent densities remain similar. This flowability enhancement with powder reuses is the opposite to the one characterized for the same material [33] but in agreement with other works for titanium alloys [21,24,26] and stainless steel [35,36]. Following the work of Sutton et. al. [36], this feature could be due either to the reduced volume fraction of small particles or particle oxidation for reused powder. Here, considering the very low oxygen content increase for the reused powder, this better flowability is probably linked to the reduction of small particle volume fraction observed on figure 2(a).

\section{III.3. Microstructure}

Density

As porosities are often observed in alloys manufactured by LPBF, it is of interest to determine whether the reusing of powder has an influence on this defect formation. An increase in the volume fraction of porosities in as-built condition will inevitably be correlated with a decrease in the material's density. Therefore, specimen density in the asbuilt condition was systematically measured using an Archimedes type balance (precision measurement of $0.01 \mathrm{~g}$ ) on 15 samples for each powder. As reference, the value of $8.32 \mathrm{~g} /$ $\mathrm{cm}^{3}$ is taken, which corresponds to the density of an as-cast sample measured with the same protocol. For samples elaborated with new powder, with respect to the reference, an average density of $98.3 \pm 0.9 \%$ was measured, whereas an average one about $98.7 \pm 0.4$ $\%$ is measured for reused powder. First of all, despite the use of 4 different lasers, porosity variation along the elaboration plate was not observed. Consequently, sample density is 
considered to be independent of the position on plate. Then, density measurements seem to indicate that powder reusing has no influence on density and porosity despite the better flowability of the reused powder reported in the former paragraphs.

In order to confirm this feature, the porosity level was also investigated using image analysis on SEM microstructure observations. Figure 3 shows typical areas of polished samples used for porosity analysis. One can see that the pores are mainly spherical and no keyhole porosities were observed. Table 4 summarizes the average value of porosity level and pores circularity obtained for samples from new (R0) and reused R50 powders. Taking into account the experimental scattering, the obtained porosity values are similar, showing that powder reusing has no effect on density samples. For both powders, the pores circularity is nearly equal to 1.0 , that indicating a perfect circle. Thus, most of pores can be considered as spherical.

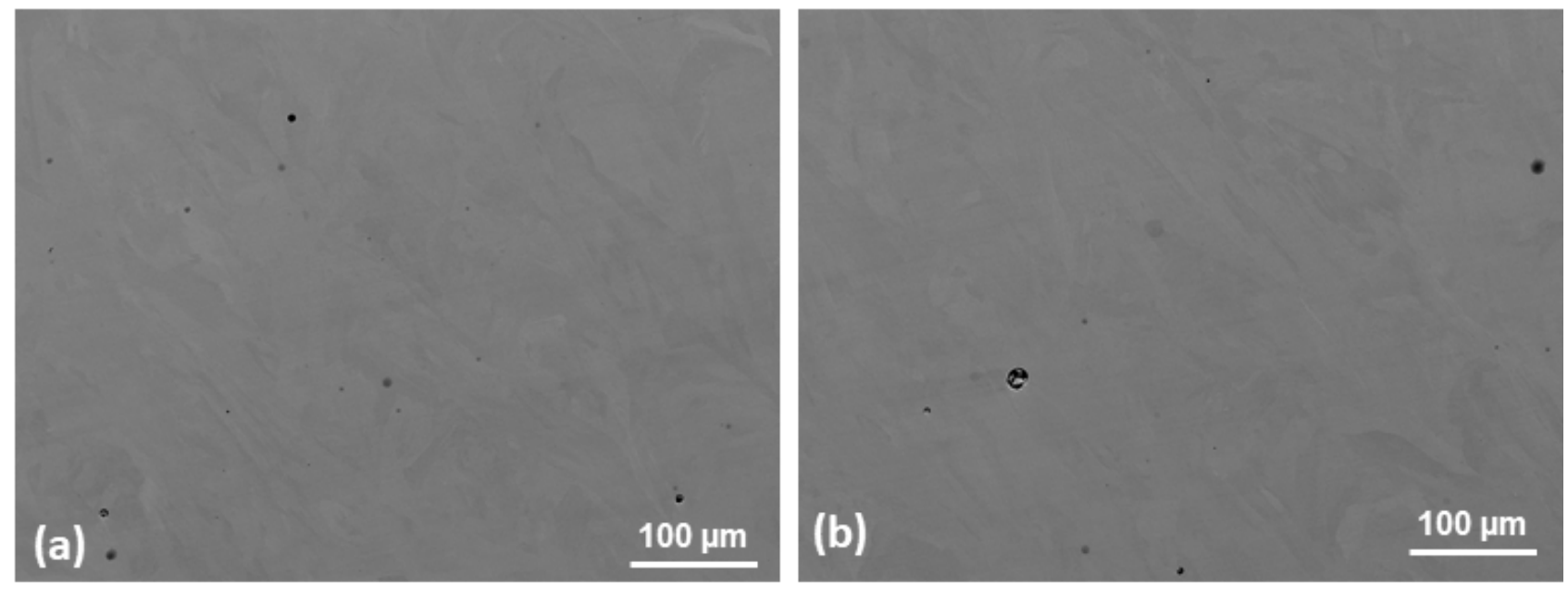

Figure 3: SEM images of polished R50 samples showing porosity in (a) horizontal section (XY) and vertical section $(X Z)$.

\section{SEM and EBSD investigations}

SEM observation on etched samples (Figure 4a-d) reveals Melt Pool Boundaries (MPB) on vertical sections of samples. Figure 4 also shows that the solidification occurs in the columnar regime. In both samples, cells are delimited by white contrast borders which are presumably Laves phases and carbides [37]. Cell size is related to the solidification rate [38]. The smallest dimension of cells size was estimated by image analysis from a dozen of high magnification images taken in the vertical plane on both samples. Automatic analysis was performed on ImageJ [39] with bandpass filtering, thresholding, followed by a local thickness measurement. Average cells sizes are $529 \pm 208 \mathrm{~nm}$ and $570 \pm 230 \mathrm{~nm}$ for 
fresh and reused powder samples, respectively. These values are in agreement with previously reported data by Pancou [40]. Thus, it can be concluded that the cooling rate was not significantly affected by powder reusing.

Figures 4c-d exhibit small black dots. On both samples, their number density is higher below the MPB than above. As discussed later in the present manuscript, those dots have been identified by TEM as $\mathrm{Al}_{2} \mathrm{O}_{3}$ nanoscaled particles. It is also seen that cells are smaller at the bottom of the melt pool than at the top but they keep the same grain orientation. Nanoscaled oxides below MPB and small cell dimensions may affect locally the mechanical behavior as it can impede dislocation movement.

EBSD analyses were performed in order to assess the size and the morphology of grains. Figures 4e-f exhibit Inverse Pole Figure (IPF) maps from vertical and horizontal planes in the center of as-built parts elaborated from new and reused powder. The represented directions are parallel to the build direction Z. Mean grain sizes and median aspect ratio estimated in vertical and horizontal planes for both materials are listed in Table 4. A misorientation threshold of $15^{\circ}$ was applied to identify grain boundaries and average grain sizes were calculated as the equivalent diameter of a circular grain having the main grain surface. Regardless of the sample, the average grain size is significantly greater in vertical planes than in horizontal planes. The largest grains are several hundred microns long along Z direction for both samples. High resolution SEM images on Figures 4c-d show that some grains are continuous through the MPB (no contrast change across MPB). Moreover, some grains in Figures 4e-f are larger than melt pools seen in Figures 4a-b. This indicates that MPB crossing may occur and that epitaxial growth is the dominant solidification mechanism [41]. White dashed lines plotted on horizontal planes in Figure $4 \mathrm{e}-\mathrm{f}$ delimit bands corresponding to the melt pool width, which result from laser patterns. On both samples, bigger and more elongated grains are found along these lines, i.e. at the boundary between consecutive melt pools. The aspect ratio of grains was evaluated to quantify grain morphology (Table 4). However, small grains are more prone to have a big aspect ratio because the step size used for EBSD acquisition may induce irrelevant smallgrains aspects. Then the median aspect ratio, $q$, value was preferred to the mean grain ratio. In the vertical plane $(Z X)$, grains are mainly elongated along the building direction in both materials with a large median aspect ratio (value of about 3 ). In the horizontal plane, grains are less elongated with a median aspect ratio of about 1.7 for both samples. Powder reuse has, hence, no significant effect on the final grain morphology. Besides, no 
obvious preferential orientation can be observed while several studies have shown a preferential orientation of grains orientation <100> along the building direction $[10,42-45]$. This difference might be connected to processing conditions that were slightly different. 

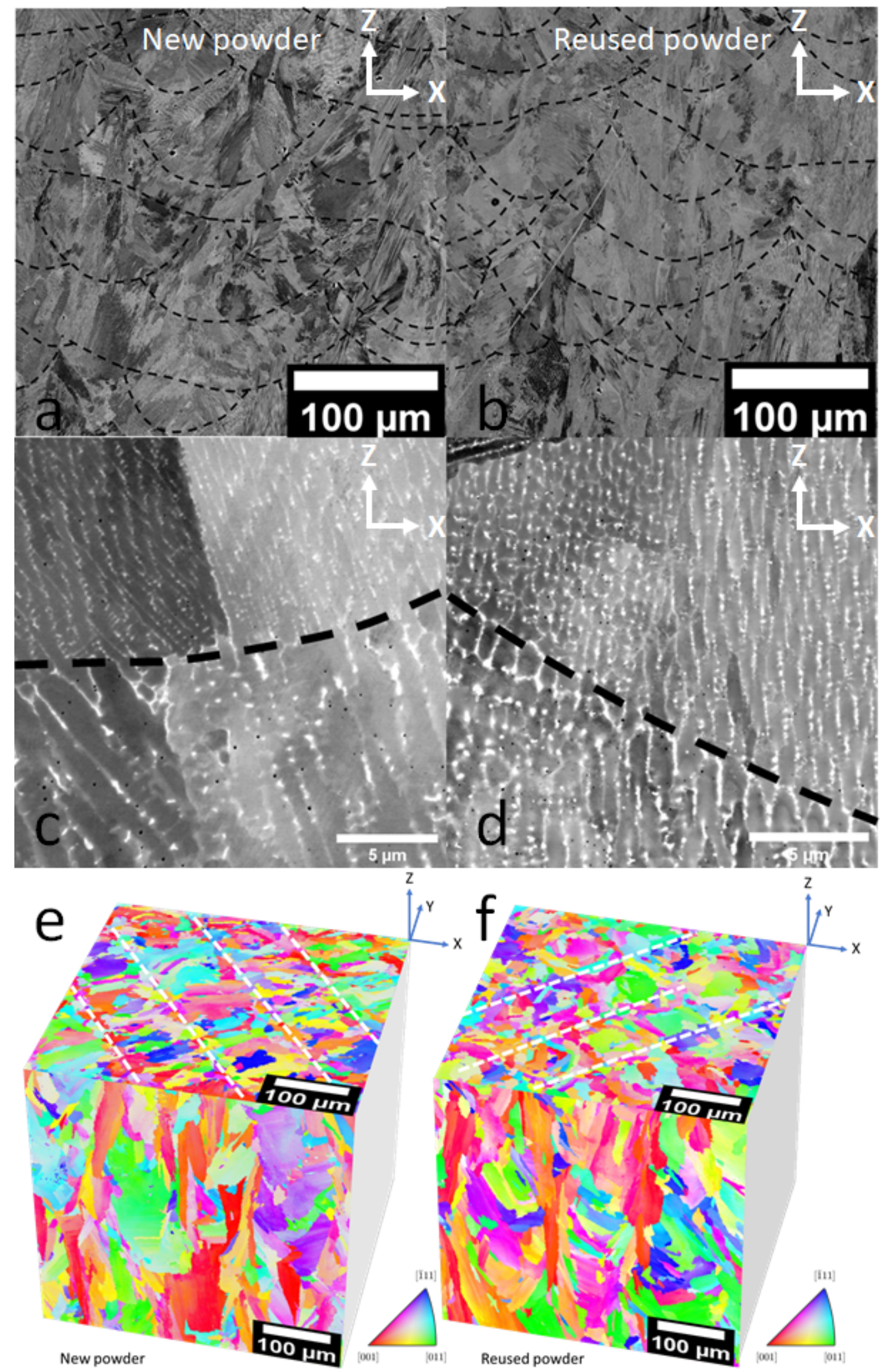

Figure 4 : Backscattered electron images at low magnification (a-b) and high magnification (c-d) and IPF (along the building direction) maps (e-f). a-c-e are related to samples manufactured with the new powder and $b-d-f$ with the 50 times reused one. Black dashed lines in a-b-c-d are MPB. White dashed lines in e-f delimit small and big grains in xy planes. 
Table 4 : Results from cell size measurements, EBSD mapping and density measurements on new (R0) and reused (R50) powder made samples for $X Y$ and $Z X$ planes.

\begin{tabular}{|c|c|c|c|c|}
\cline { 2 - 5 } \multicolumn{1}{c|}{} & \multicolumn{2}{c|}{ R0 samples } & \multicolumn{2}{c|}{ R50 samples } \\
\cline { 2 - 5 } & XY & ZX & XY & ZX \\
\hline Mean Grain Size ( $\mu \mathrm{m})$ & $12.3 \pm 7.8$ & $19.4 \pm 7.5$ & $13.0 \pm 8.4$ & $19.9 \pm 12.7$ \\
\hline Median Aspect Ratio (-) & $1.73 \pm 0.65$ & $2.94 \pm 1.38$ & $1.76 \pm 0.6$ & $3.02 \pm 1.4$ \\
\hline Porosity level (\%) & $0.19 \pm 0.09$ & $0.23 \pm 0.04$ & $0.14 \pm 0.05$ & $0.27 \pm 0.17$ \\
\hline Pores circularity (-) & $0.95 \pm 0.03$ & $0.93 \pm 0.01$ & $0.90 \pm 0.04$ & $0.92 \pm 0.03$ \\
\hline Cell size (nm) & \multicolumn{2}{|c|}{$529 \pm 208$} & \multicolumn{2}{c}{$570 \pm 230$} \\
\hline
\end{tabular}

\section{TEM investigations}

TEM investigations were performed to collect information at a smaller scale. Figure 5 shows bright field Scanning Transmission Electron Microscopy (STEM) images of the material obtained with fresh and reused powders. A high dislocation density and two kinds of particles (with dark contrast at interdendritic boundaries and with bright contrast mainly located inside grains) are clearly exhibited. EDX analyses were carried out to identify these particles (Figure 6). Three kinds of phases could be identified: 1) Al and O rich particles, presumably aluminum oxide; 2) $\mathrm{Ti}, \mathrm{Nb}$ and $\mathrm{C}$ rich particles, presumably $\mathrm{MC}$ carbides ; 3) $\mathrm{Nb}$ and Ti rich particles, presumably lave phases [46]. Al and O rich particles are known to have a good thermal stability and have been characterized even after high temperature heat treatments [47]. Selected Area Electron Diffraction (SAED) rings shown in Figure 7 inset that it is composed of really fine crystallites. The STEM bright field image in Figure 8 shows that such $\mathrm{Al}_{2} \mathrm{O}_{3}$ particles are often spherical and are eventually covered by another phase with a dark contrast. EDX analysis revealed that, indeed, the $\mathrm{Al}_{2} \mathrm{O}_{3}$ particle served the $\mathrm{MC}$ carbides to preferential nucleation. However, oxides contribution to mechanical properties should be negligible since density (around $10^{18} \mathrm{~m}^{-3}$ ) and size (around $60 \mathrm{~nm}$ ) for both samples do not induce significant hardening.

In IN718, precipitation hardening is achieved with the dense precipitation of $y^{\prime}$ and $y^{\prime \prime}$ phases. To check if significant precipitation occurred during thermal cycles after solidification, samples were oriented in [100] zone axis. However, since no superlattice reflections associated with these phases could be exhibited on SAED patterns, it is hence inferred that $y^{\prime}$ and $y^{\prime \prime}$ are not formed in the as-built condition. DF-STEM imaging was also carried out and no precipitates could not be imaged neither. 

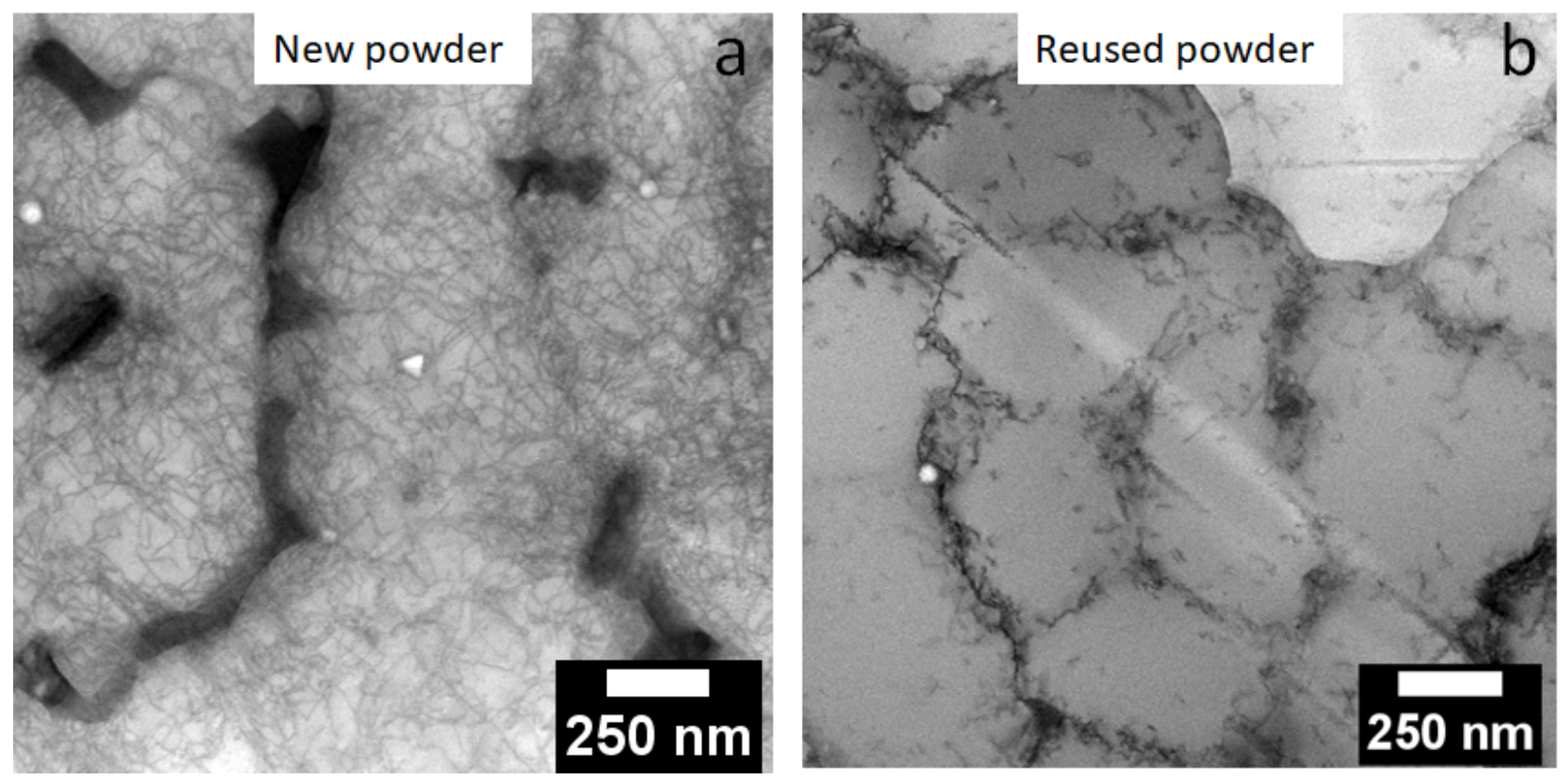

Figure 5 : Bright field STEM images of new powder and reused powder made samples. Dislocation walls, Laves phases, carbides and Al2O3 particles are present in both samples.
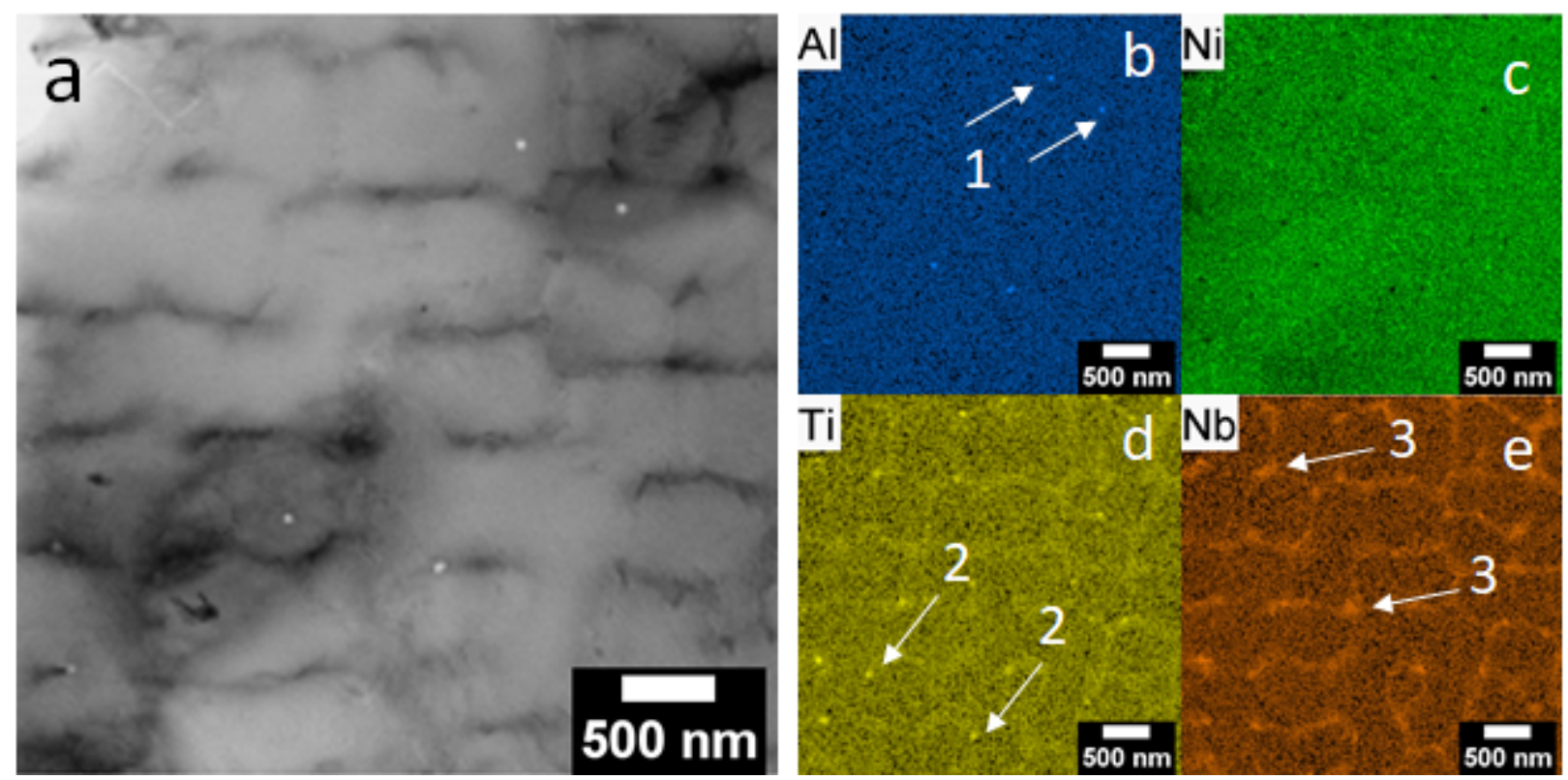

Figure 6 : STEM bright field image (a) and EDX analysis (b-c-d-e) at low magnification of new powder sample (R0). Intercellular region is enriched in $\mathrm{Nb}$ and Ti. This analysis also emphasizes the presence of Al2O3 precipitates and Ti carbides. 


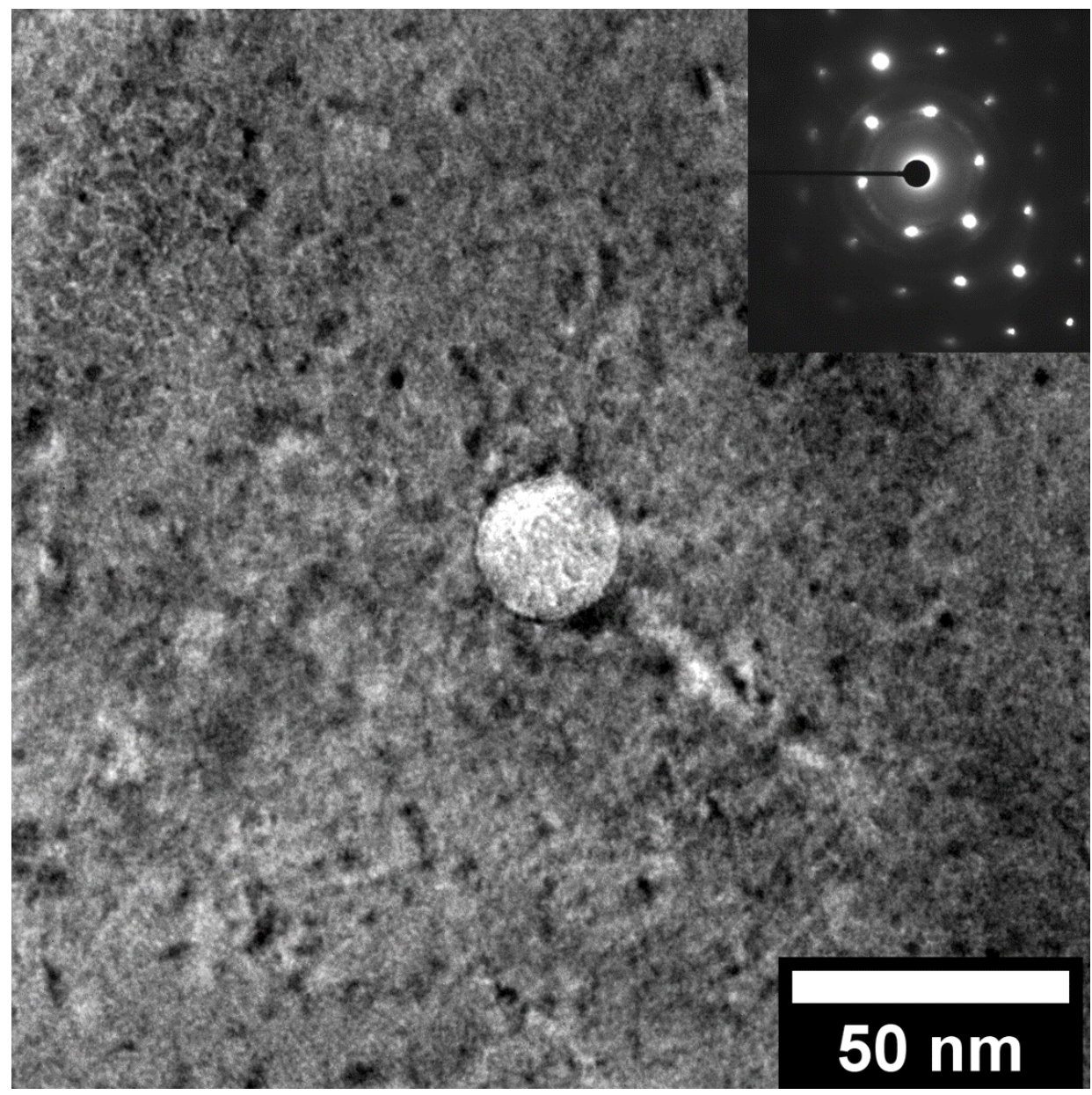

Figure 7 : Bright field TEM image showing Al2O3 particle and the associated SAED in new powder made sample. Matrix is close to [110] zone axis.

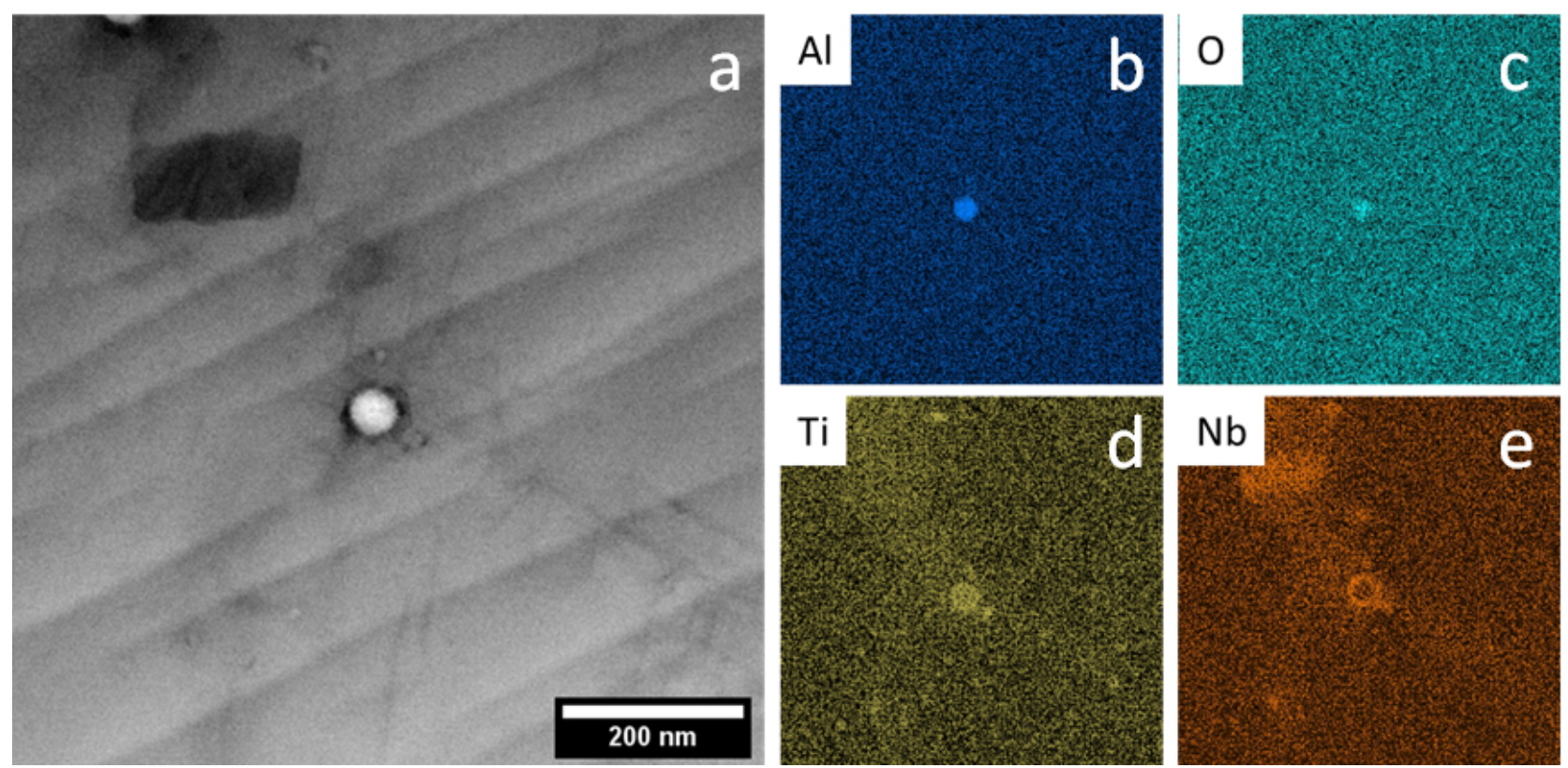

Figure 8 : STEM bright field image (a) of new powder made sample and associated EDX element maps (b-c-d-e) showing an Al2O3 particle surrounded by a shell enriched in $\mathrm{Ti}$ and $\mathrm{Nb}$. 


\section{Atom probe tomography (APT)}

To measure the matrix composition and evaluate the potential hardening capacity thanks to a post-LPBF aging treatment, materials were analyzed by APT. Besides, this technique may reveal some early stage of precipitation (clustering) if any. Visual inspection of threedimensional reconstructions of analyzed volumes show a homogeneous distribution of $\mathrm{Al}$ and $\mathrm{Nb}$ in both materials (Figure 9a). Since these elements strongly partition in $\mathrm{y}^{\prime}$ and $\mathrm{y}^{\prime \prime}$ phases, it indicates that precipitates have not nucleated and grown during thermal cycles after solidification, in agreement with our TEM observations. To quantify if clustering occurred, radial distribution function for $\mathrm{Nb}$ atoms were calculated (Figure 9b). This statistical analysis does not show any significant clustering. The matrix composition estimated from those analyzed volumes are displayed in Table 5. Oxygen content in solid solution in the matrix is significantly higher in the material build from reused powders (0.011 \pm 0.003 at.\% against $0.003 \pm 0.0016$ at.\%). These values are lower than those obtained by ICP (see Table 2) for manufactured samples with the new R0 powder (0.011 \pm 0.01 at.\%) and reused R50 powder (0.058 \pm 0.01 at.\%). Indeed, numerous Al2O3 particles that have captured a significant amount of oxygen and values reported in Table 5 are related to atoms left in solid solution in the matrix. The detected aluminum content is slightly higher for the fresh powder $(1.4$ at. $\% \pm 0.0074)$ than for the reused powder (1.2 at. $\% \pm 0.009)$. These measurements show that the amount of Al left in solid solution is significantly reduced in the material built from reused powders (by about 0.2 at.\%), probably due to a slightly higher volume fraction of $\mathrm{Al} 2 \mathrm{O}$. 
a) New powder
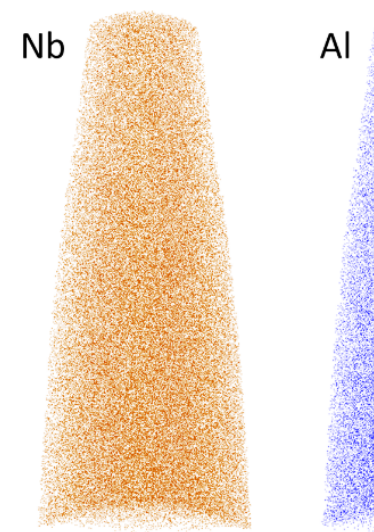

$\mathrm{Al}$
Reused powder

b)
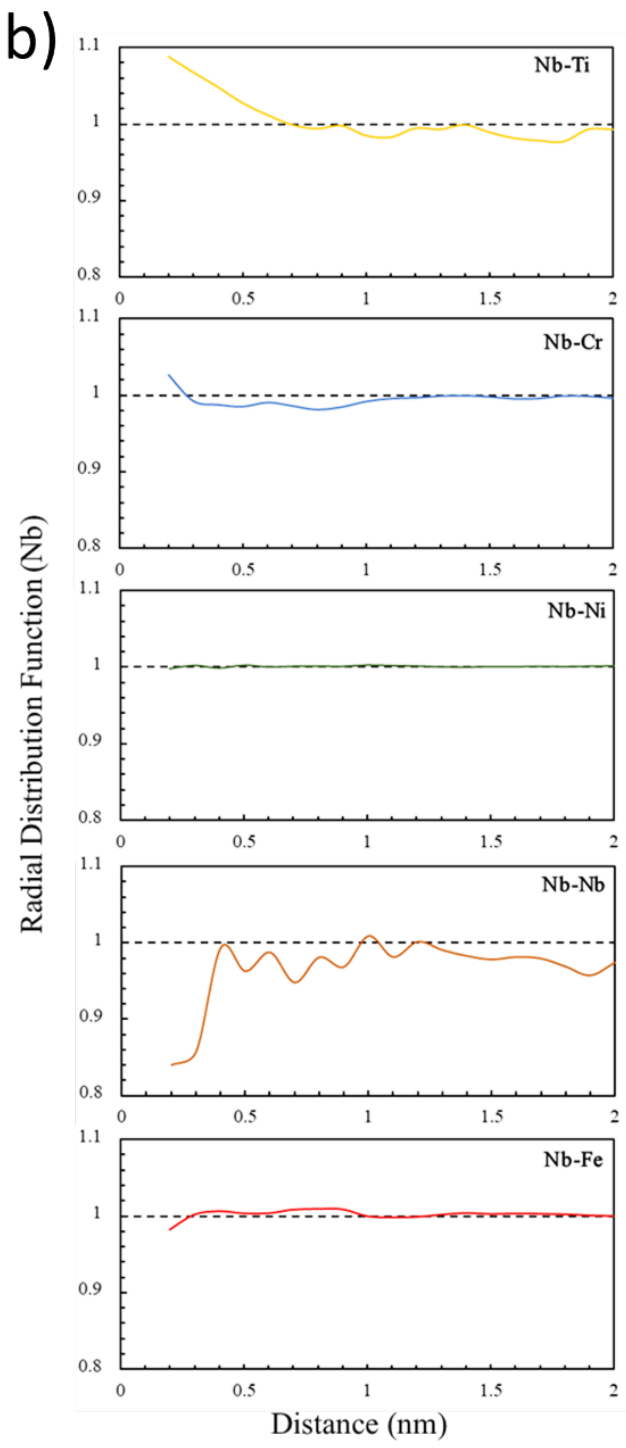

Al
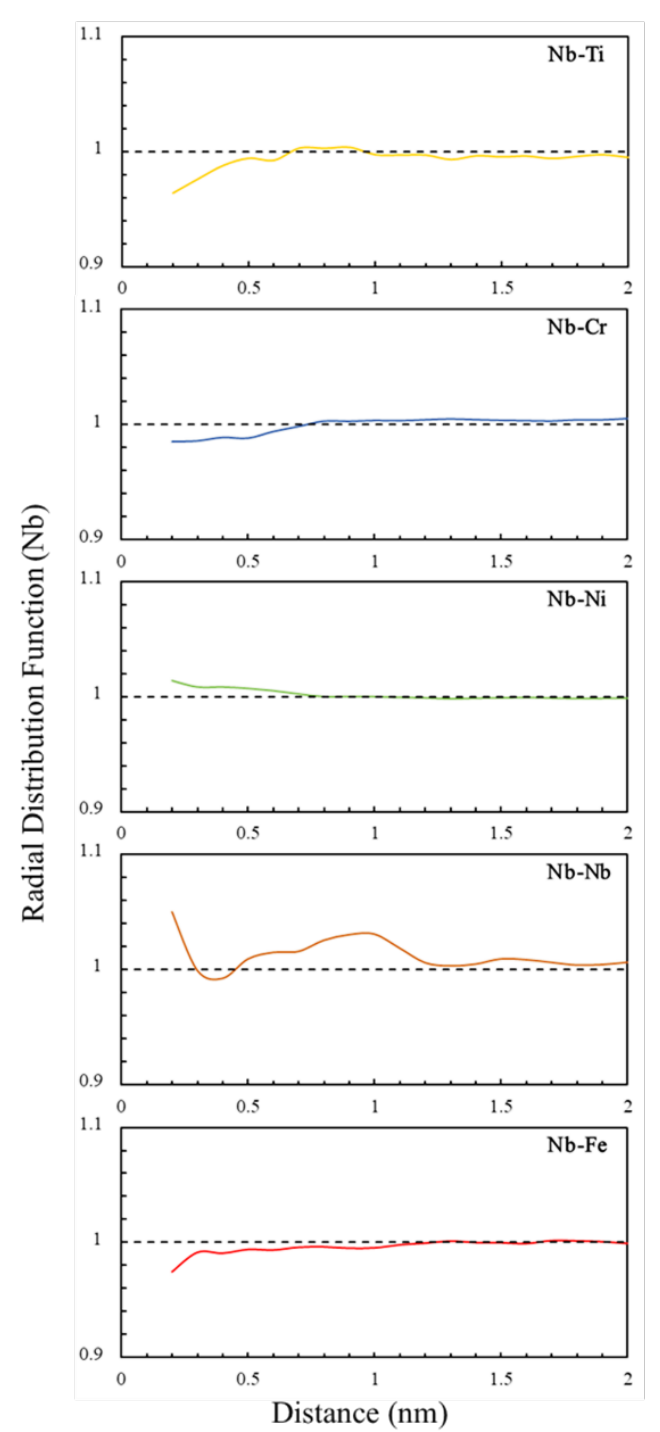

Figure 9 : Reconstructed APT volumes from new (50*50*125nm3) and reused powder (50*50*84 $\mathrm{nm} 3) \mathrm{made}$ samples with b) corresponding Radial Distribution Functions (RDF) for Nb ions. 
Table 5 : Composition of APT volumes from new and reused samples.

\begin{tabular}{|c|c|c|c|c|}
\hline & \multicolumn{3}{|l|}{ New powder } & Reused powder \\
\hline Ion & At \% & At err (\%) & At \% & At err (\%) \\
\hline C & $0.008 \%$ & $\pm 0.0021 \%$ & $0.015 \%$ & $\pm 0.002 \%$ \\
\hline O & $0.003 \%$ & $\pm 0.0016 \%$ & $0.011 \%$ & $\pm 0.003 \%$ \\
\hline $\mathbf{N b}$ & $3.048 \%$ & $\pm 0.0096 \%$ & $2.970 \%$ & $\pm 0.014 \%$ \\
\hline Mo & $2.176 \%$ & $\pm 0.0086 \%$ & $2.114 \%$ & $\pm 0.012 \%$ \\
\hline $\mathbf{A l}$ & $1.400 \%$ & $\pm 0.0074 \%$ & $1.196 \%$ & $\pm 0.009 \%$ \\
\hline $\mathbf{S i}$ & $0.049 \%$ & $\pm 0.0059 \%$ & $0.087 \%$ & $\pm 0.025 \%$ \\
\hline $\mathbf{T i}$ & $1.345 \%$ & $\pm 0.0060 \%$ & $1.142 \%$ & $\pm 0.009 \%$ \\
\hline $\mathbf{V}$ & $0.007 \%$ & $\pm 0.0020 \%$ & $0.013 \%$ & $\pm 0.002 \%$ \\
\hline $\mathbf{C r}$ & $20.478 \%$ & $\pm 0.0180 \%$ & $20.047 \%$ & $\pm 0.027 \%$ \\
\hline $\mathbf{M n}$ & $0.015 \%$ & $\pm 0.0012 \%$ & $0.021 \%$ & $\pm 0.002 \%$ \\
\hline $\mathbf{F e}$ & $19.538 \%$ & $\pm 0.0184 \%$ & $19.231 \%$ & $\pm 0.027 \%$ \\
\hline $\mathbf{C o}$ & $0.060 \%$ & $\pm 0.0000 \%$ & $0.072 \%$ & $\pm 0.003 \%$ \\
\hline $\mathbf{N i}$ & $51.933 \%$ & $\pm 0.0242 \%$ & $53.070 \%$ & $\pm 0.037 \%$ \\
\hline
\end{tabular}

Based on the SEM, TEM and APT analysis of samples manufactured with the new and 50 times reused powder, it is clear that powder reusing, does not significantly affect the microstructure, even down to the atomic scale. To confirm the good re-usability of IN718 powder, mechanical properties were also characterized in the following paragraphs.

\section{III.2. Mechanical properties}

\section{Tensile tests}

Table 6 displays mechanical properties values extracted from tensile tests performed on new powder and reused powder samples. Error bars are linked to the parameter's determination errors.

Except for the UTS which exhibits a slight increase with powder reuse, these data do not show any significant mechanical behavior difference, indicating that powder reusing has little effect on the monotonous tensile behavior. 
Table 6 : Tensile properties along building direction for new-powder (R0) and reused-powder (R50) made samples. The samples have been characterized as-received.

\begin{tabular}{|c|c|c|c|c|}
\hline & $\begin{array}{c}\text { Yield stress } \\
\sigma_{0.2}(\mathrm{MPa})\end{array}$ & $\begin{array}{c}\text { Ultimate tensile } \\
\text { stress } \sigma_{\text {UTS }} \\
(\mathrm{MPa})\end{array}$ & $\begin{array}{c}\text { Uniform } \\
\text { elongation (\%) }\end{array}$ & $\begin{array}{c}\text { Elongation to failure } \\
\mathrm{A}(\%)\end{array}$ \\
\hline R0 samples & $671 \pm 5$ & $1015 \pm 4$ & $27 \pm 2$ & $49 \pm 2$ \\
\hline $\begin{array}{c}\text { R50 samples } \\
\text { SLM literature in the as- } \\
\text { received state } \\
{[10,18,30,41,42]}\end{array}$ & $677 \pm 5$ & $1025 \pm 4$ & $27 \pm 2$ & $51 \pm 2$ \\
\hline
\end{tabular}

Tested samples are in good agreement with data reported in the literature for similar alloys processed by SLM without age hardening heat-treatment $[10,19,37,48,49]$.

\section{Cyclic Stress-Strain Curves (CSSC)}

Cyclic Stress-Strain Curves of samples elaborated from new (black) and reused (red) powder are plotted in Figure 10. As in the tensile condition, no significant difference is observed depending on the powder types. The total strain varies from $10^{-4}$ to $10^{-1}$ which leads to a plastic strain variation from $10^{-5}$ to $10^{-2}$. The evolution of stress amplitude (Figure 10a) can be described linearly with a slope change around $10^{-3}$ plastic strain. Powder bed fusion processes usually introduced residual stresses into the materials [1]. Mean stress evolution along plastic strain is shown in Figure 10b. Independently on the plastic strain amplitude, these mean stresses are negative which indicates compressive residual stresses. For plastic strain amplitude lower than $5.10^{-4}$, corresponding to microplasticity (only the well oriented grains with respect to the loading direction are expected to deform plastically with one activated slip system), the mean stress decreases with an increase in plastic strain amplitude. The mean stress reach then a minimum around $5.10^{-4}$ of plastic strain amplitude which is close to the onset of homogeneous plasticity (yield locus crossed). Therefore, this minimal mean stress value, about -60 MPa, can be considered in first approximation, to be equal to the average residual stress in the building direction. This value is in agreement with the average value that have been reported for the same material using neutron diffraction and numerical simulation [50]. Considering the experimental scattering, no clear difference in minimal mean stress is observed between the two samples series, revealing no influence of the powder type on the residual stresses. For larger plastic strain amplitudes, corresponding to generalized plasticity, the formation 
of dislocation structures related to the plastic deformation strongly modify the initial microstructure which, in turn, is expected to soften the residual stresses. These residual stresses can affect the fatigue life [51] and thus may explain the lower fatigue life of LPBF manufactured IN718 compared to ones elaborated from conventional methods [9,37,52].

Based on the CSSC, 3 strain amplitudes (illustrated in Figure 10 by vertical dashed lines) were chosen to perform fatigue tests in the two plastic domains described above (i.e. microplasticity and generalized plasticity) and in the transition between both domains.
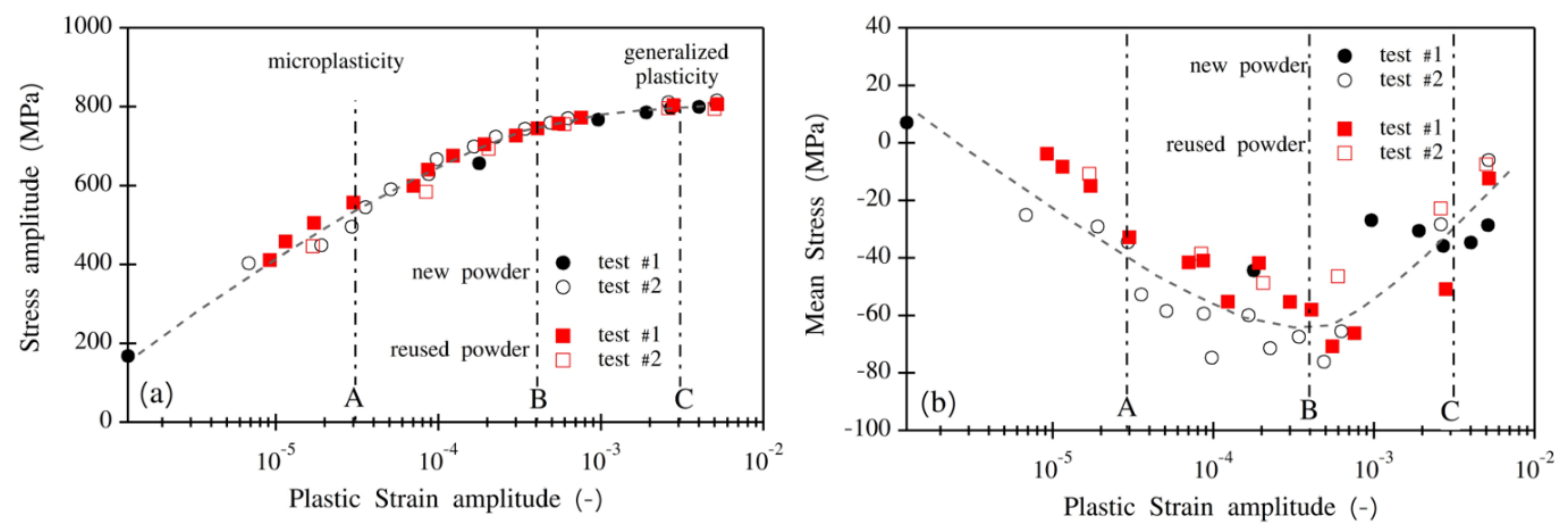

Figure 10 : Comparison between the cyclic stress-strain curves of samples elaborated from new (R0black) and reused (R50-red) powder. (a) Evolution of stress amplitude with plastic strain and b) evolution of mean stress with plastic strain. Vertical dashed lines correspond to strain amplitude selected for fatigue tests. Only two sample curves have been plotted for each kind of sample.

\section{Fatigue tests}

Fatigue tests were performed to assess the effect of powder reusing on fatigue life. For tests performed with a total deformation equal to $7.510^{-3}$ and $4.2510^{-3}$, stress amplitude and mean stress can be extracted from each cycle. In order to decrease the amount of data collected on fatigue tests with a total deformation of $2.7510^{-3}$, analyses were performed every 25 cycles for the first 10000 cycles then every 10000 cycles until the end of the test. Cycles to failure values are rounded to the nearest thousand. Fatigues tests data are summarized in Table 7. 

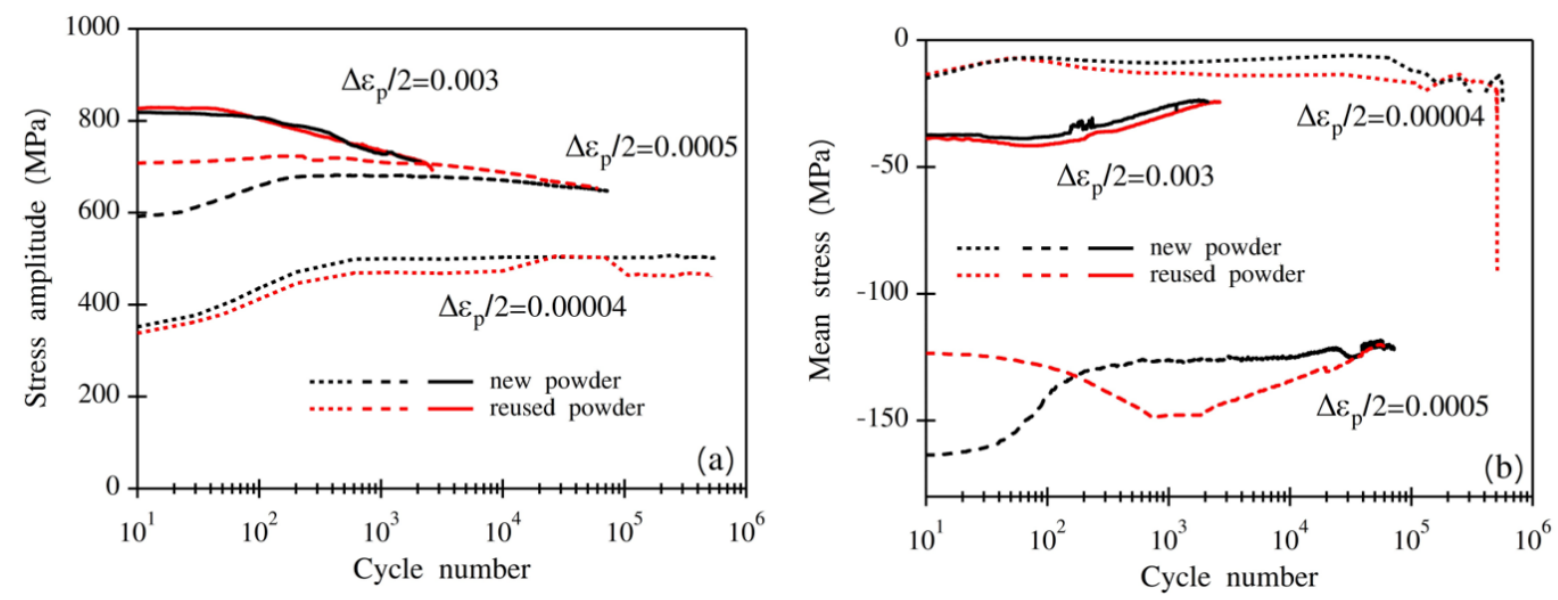

Figure 11 : Example of the evolution of stress amplitude and mean stress during fatigue tests for different stress amplitudes

The stress amplitude and the mean stress significantly evolve during fatigue tests (Figure 11). For each test series, the plastic strain amplitude is inserted in this figure. It could be noted that this amplitude corresponds to that expected from CSSC curves. The data plotted for a number of cycles larger than 100 correspond to cycles that reach the selected total strain amplitude. From such curves, experimental values including softening magnitudes were estimated and have been listed in Table 7.

First, in agreement with microstructural data, the difference between samples elaborated from new or reused powders is relatively low: average stress amplitude is slightly lower and the mean stress amplitude slightly larger (absolute value) for samples elaborated with the reused powder. Then, as expected while increasing the total deformation, the plastic strain amplitude and the stress amplitude increase whereas the number of cycles to failure decreases. Moreover, when the plastic deformation increases of one magnitude order, the number of cycles to failure decreases to one magnitude order. As predicted by CSSC curves a softening of mean stress amplitude (mean stress increases to approach 0 ) is observed for a total strain amplitude of $2.7510^{-3}$ and $7.510^{-3}$. However, for a total strain amplitude of $4.2510^{-3}$ corresponding to the maximum absolute mean stress observed in CSSC curves, it is not possible to erase this residual stress. Finally, one may notice in Table 7 that the higher is the total strain, the higher is the softening of stress amplitude. 
Table 7 : Fatigue tests results. The number of cycles to failure for a total deformation of $2.7510^{-3}$ are round to the nearest thousand. " $x$ " means that the noticed variation is around an average value and neither softening nor hardening is observed. "?" means that the data are too noisy to extract the plastic deformation. Errors bars associated to the average plastic strain amplitude, stress amplitude and mean stress are related to the variation of these parameter over the cycle range of computation.

\begin{tabular}{|c|c|c|c|c|c|c|c|}
\hline & \begin{tabular}{|l|} 
Total strain \\
amplitude
\end{tabular} & $\begin{array}{l}\text { Average } \\
\text { plastic strain } \\
\text { amplitude }\end{array}$ & $\begin{array}{l}\text { Average } \\
\text { stress } \\
\text { amplitude } \\
(\mathrm{MPa})\end{array}$ & $\begin{array}{l}\text { Average } \\
\text { mean } \\
\text { stress } \\
(\mathrm{MPa})\end{array}$ & $\begin{array}{l}\text { Stress } \\
\text { amplitude } \\
\text { variation } \\
(\mathrm{MPa})\end{array}$ & $\begin{array}{l}\text { Mean } \\
\text { stress } \\
\text { variation } \\
(\mathrm{MPa})\end{array}$ & $\begin{array}{l}\text { Cycles to } \\
\text { failure }\end{array}$ \\
\hline Ro \#1 & \multirow{3}{*}{$\begin{array}{c}2.7510^{-3}(\mathrm{C} \text { in } \\
\text { Fig. } 8 \mathrm{a})\end{array}$} & $(3.5 \pm 1) 10^{-5}$ & $524 \pm 2$ & $-10 \pm 6$ & $x$ & 12 & 346000 \\
\hline Ro \#2 & & $(3.0 \pm 1) 10^{-5}$ & $502 \pm 3$ & $-15 \pm 4$ & $x$ & 18 & 572000 \\
\hline Ro \#3 & & $(2.5 \pm 1) 10^{-5}$ & $482 \pm 2$ & $-31 \pm 5$ & $x$ & 17 & 580000 \\
\hline R50 \#1 & \multirow{3}{*}{$\begin{array}{c}2.7510^{-3}(\mathrm{C} \text { in } \\
\text { Fig. 8a })\end{array}$} & $?^{1}$ & $497 \pm 17$ & $-33 \pm 7$ & $x$ & 14 & 409000 \\
\hline R50 \#2 & & $(5.0 \pm 2) 10^{-5}$ & $536 \pm 2$ & $-35 \pm 11$ & $x$ & 4 & 148000 \\
\hline R50 \#3 & & $(2.5 \pm 2) 10^{-5}$ & $460 \pm 10$ & $-39 \pm 9$ & $x$ & 13 & 512000 \\
\hline Ro \#1 & \multirow{3}{*}{$\begin{array}{l}4.2510^{-3} \text { (B in } \\
\text { Fig. 8a) }\end{array}$} & $(4.0 \pm 0.5) 10^{-4}$ & $693 \pm 11$ & $-86 \pm 2$ & -61 & $x$ & 26961 \\
\hline Ro \#2 & & $(6.0 \pm 2) 10^{-4}$ & $692 \pm 14$ & $-23 \pm 3$ & -55 & $x$ & 18458 \\
\hline R0 \#3 & & $(4.0 \pm 0.5) 10^{-4}$ & $660 \pm 8$ & $-122 \pm 2$ & -73 & $x$ & 72426 \\
\hline R50 \#1 & \multirow{3}{*}{$\begin{array}{l}4.2510^{-3} \text { (B in } \\
\text { Fig. } 8 \mathrm{a})\end{array}$} & $(6.0 \pm 1) 10^{-4}$ & $669 \pm 12$ & $-127 \pm 5$ & -71 & $x$ & 58097 \\
\hline R50 \#2 & & $(5.0 \pm 2) 10^{-4}$ & $681 \pm 9$ & $-34 \pm 2$ & -77 & $x$ & 28373 \\
\hline R50 \#3 & & $(5.0 \pm 1) 10^{-4}$ & $660 \pm 9$ & $-74 \pm 3$ & -86 & $x$ & 29279 \\
\hline Ro \#1 & \multirow{3}{*}{$\begin{array}{l}7.510^{-3} \text { ( } \mathrm{A} \text { in Fig. } \\
8 \mathrm{a})\end{array}$} & $(3.1 \pm 0.1) 10^{-3}$ & $738 \pm 14$ & $-7 \pm 2$ & -125 & 30 & 3146 \\
\hline Ro \#2 & & $(3.2 \pm 0.2) 10^{-3}$ & $725 \pm 15$ & $-25 \pm 2$ & -133 & 15 & 2106 \\
\hline R0 \#3 & & $(2.8 \pm 0.3) 10^{-3}$ & $721 \pm 13$ & $-8 \pm 3$ & -260 & 38 & 2783 \\
\hline R50 \#1 & \multirow{3}{*}{$\begin{array}{l}7.510^{-3}(\mathrm{~A} \text { in Fig. } \\
8 \mathrm{a})\end{array}$} & $(3.0 \pm 0.2) 10^{-3}$ & $722 \pm 16$ & $-27 \pm 3$ & -131 & 18 & 3094 \\
\hline R50 \#2 & & $(3.3 \pm 0.1) 10^{-3}$ & $725 \pm 16$ & $-26 \pm 2$ & -151 & 15 & 2650 \\
\hline R50 \#3 & & $(2.7 \pm 0.3) 10^{-3}$ & $706 \pm 14$ & $-6 \pm 2$ & -120 & 16 & 4825 \\
\hline
\end{tabular}

The stresses amplitude as a function of the number of cycles to failure are plotted in Figure 12 (SN curve). For the highest total strain (high stress), no difference between samples from new and reused are exhibited. However, for lower total strain (low stress), samples made with reused powder tends to have a lower fatigue resistance. Experimental results were fitted with the power law of Basquin's model reported in Eq1. [9].

$\sigma=A N^{B} E q 1$

In this equation, $A$ and $B$ are materials constant, $\sigma$ the average stress amplitude and $\mathrm{N}$ the number of cycles to failure. Basquin's model provided a good fit of our experimental values even for a high number of cycles $\left(10^{5}\right)\left(R^{2}=0.97\right.$ and 0.95 for new and reuse powder respectively). Fitting parameters are listed in Table 8 . Value for $A$ is slightly larger in the 
case of reused powder meaning that for a single cycle, a sample made with the reused powder will present a larger ultimate stress, which is fully consistent with tensile tests results for reused powder made samples (see Table 6). Same trend is observed for $B$ parameter. A larger value of $B$ (in absolute value) means a more ductile materials and thus a lower fatigue life. It is consistent with the slightly higher elongation to failure that is measured on the tensile curve of the sample made from reused powder.

$A$ and $B$ values extracted from literature are also given for comparison in Table 8. For a study carried out in similar conditions ( $R=-1$, machined samples) [9], A and $B$ values are in agreement with their higher UTS and lower elongation to failure (i.e. UTS=1406 MPa and fracture strain 13,6\%). Concerning the second set of data [12], parameter $A$ is similar which is consistent with our similar UTS. However, their lower fatigue resistance (stress < $400 \mathrm{MPa}$ event for $\mathrm{N}<10^{5}$ ) as compared to the present study can probably be explained by a different surface finishing (machining removes surface defects and then improves fatigue life).

However, the difference in the fit of our data for new and reused powders is lower than the difference between 2 samples elaborated using a given powder. It further demonstrates that powder recycling does affect as much final mechanical properties as elaboration conditions. Despite the small variations observed for small strain amplitude fatigue test, this mechanical investigation validates the capability of high-number reused powder to build high qualities IN718 parts.

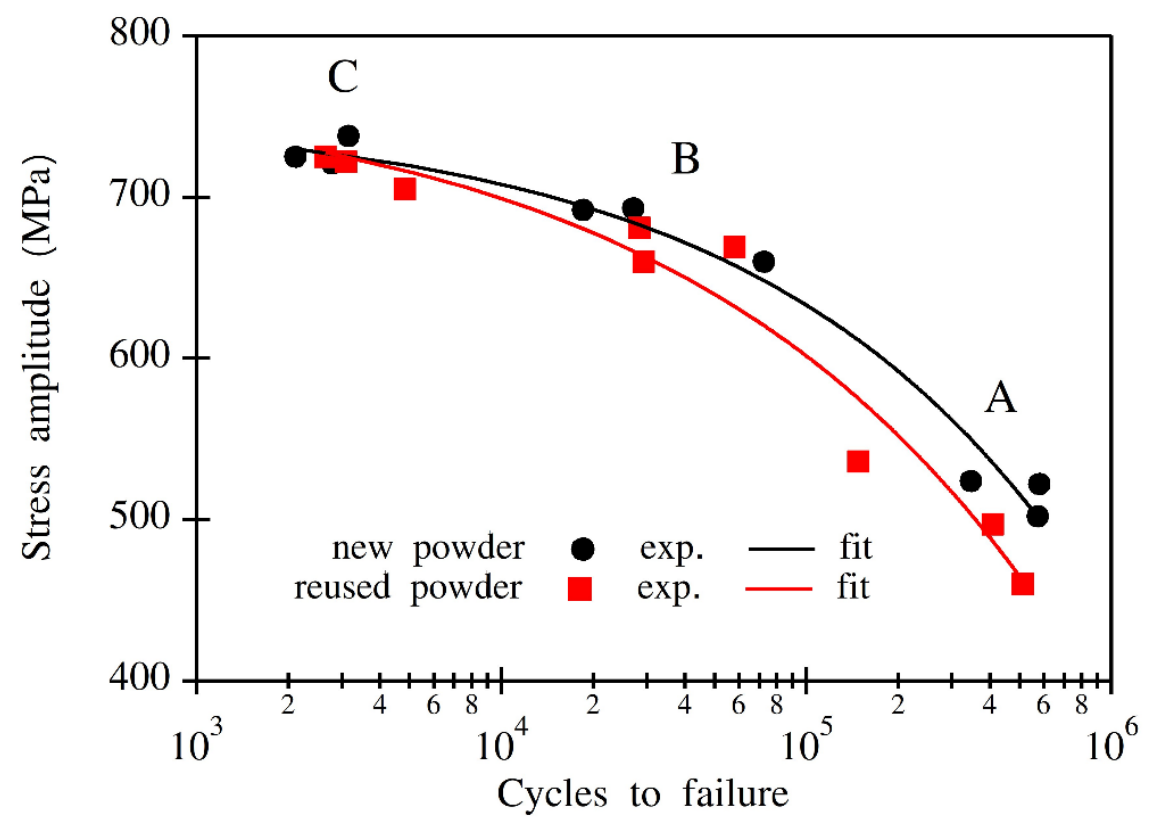

Figure 12 : Comparison of SN curves for samples elaborated from new (black) and reused (red) powder. Lines correspond to the fit. 
Table 8 : Parameters of the Basquin's model for samples elaborated with new and reused powder

\begin{tabular}{|c|c|c|}
\hline & A (MPa) & B \\
\hline New & 1176 & -0.81 \\
\hline Reused & 1437 & -0.85 \\
\hline Literature & & \\
R=-1 machined [9] & 2153 & -0.11 \\
R=0.1 as-build [12] & 1761 & -0.20 \\
\hline
\end{tabular}

\section{Conclusions}

For cost limitation and sustainable development, one challenge of powder bed fusion processes is to be able to reuse unmelt powders after each fabrication. The impact of 50 powder reuses on microstructure and mechanical properties of laser powder bed fusion produced Inconel 718 has been assessed for such purpose. The main conclusions can be listed as follows:

1/ Oxygen content is slightly increased in reused powder and associated manufactured samples but remains in the aeronautic standards.

2/ Powder flowability is significantly increased after the 50 production cycles of the reused powder probably due to both small particles reduction and particle oxidation. No effect is observed on porosity rate.

3/ the solidification process is not affected by the kind of powder as both dendrite size, grain size and morphology and texture are similar for both sample batches (new and reused powder based).

4/ Atom probe tomography does not reveal any chemical element clustering or $y^{\prime}$ and $y^{\prime \prime}$ precipitates formation.

$5 /$ Monotonic tensile properties are not modified by the 50 production cycles of the reused powder. In cyclic conditions, similar average -60 MPa residual stress is reported for both powder type. 
6/ In fatigue, a slight reduction in fatigue life is observed for reused powder-based samples for small plastic amplitude loadings. This average fatigue life difference is, nevertheless, of the same order than the result scattering for one given loading and kind of sample.

This work demonstrates that, if the recycling is correctly performed following high-quality procedure, the final material properties still fulfill the requirements for industrial applications, even after a high number of building jobs. Further work is in progress to investigate the influence of the powder recycling on the microstructure and mechanical properties after solution annealing and subsequent ageing of the samples.

\section{Acknowledgments}

The Normandy Region and European Union (European Regional Development Fund) are greatly acknowledged for the financial support of the CLIP FAM project. Yan Duval is also acknowledged for the help on the fatigue data treatment.

\section{Data availability statement}

The raw/processed data required to reproduce these findings cannot be shared at this time as the data also forms part of an ongoing study.

\section{References}

[1] T. DebRoy, H.L. Wei, J.S. Zuback, T. Mukherjee, J.W. Elmer, J.O. Milewski, A.M. Beese, A. Wilson-Heid, A. De, W. Zhang, Additive manufacturing of metallic components Process, structure and properties, Progress in Materials Science. 92 (2018) 112-224. https://doi.org/10.1016/j.pmatsci.2017.10.001.

[2] M.G. Rashed, M. Ashraf, R.A.W. Mines, P.J. Hazell, Metallic microlattice materials: A current state of the art on manufacturing, mechanical properties and applications, Materials \& Design. $95 \quad$ (2016) 518-533. https://doi.org/10.1016/j.matdes.2016.01.146.

[3] I. Yadroitsev, Ph. Bertrand, I. Smurov, Parametric analysis of the selective laser melting process, Applied Surface Science. 253 (2007) 8064-8069. https://doi.org/10.1016/j.apsusc.2007.02.088. 
[4] C.Y. Yap, C.K. Chua, Z.L. Dong, Z.H. Liu, D.Q. Zhang, L.E. Loh, S.L. Sing, Review of selective laser melting: Materials and applications, Applied Physics Reviews. 2 (2015) 041101. https://doi.org/10.1063/1.4935926.

[5] K.N. Amato, S.M. Gaytan, L.E. Murr, E. Martinez, P.W. Shindo, J. Hernandez, S. Collins, F. Medina, Microstructures and mechanical behavior of Inconel 718 fabricated by selective laser melting, Acta Materialia. $60 \quad$ (2012) 2229-2239. https://doi.org/10.1016/j.actamat.2011.12.032.

[6] J. Kruth, P. Mercelis, J. Van Vaerenbergh, L. Froyen, M. Rombouts, Binding mechanisms in selective laser sintering and selective laser melting, Rapid Prototyping Journal. 11 (2005) 26-36. https://doi.org/10.1108/13552540510573365.

[7] C. Zhao, K. Fezzaa, R.W. Cunningham, H. Wen, F.D. Carlo, L. Chen, A.D. Rollett, T. Sun, Real-time monitoring of laser powder bed fusion process using high-speed X-ray imaging and diffraction, Sci Rep. 7 (2017) 1-11. https://doi.org/10.1038/s41598-01703761-2.

[8] K. Moussaoui, W. Rubio, M. Mousseigne, T. Sultan, F. Rezai, Effects of Selective Laser Melting additive manufacturing parameters of Inconel 718 on porosity, microstructure and mechanical properties, Materials Science and Engineering: A. 735 (2018) 182-190. https://doi.org/10.1016/j.msea.2018.08.037.

[9] C. Pei, D. Shi, H. Yuan, H. Li, Assessment of mechanical properties and fatigue performance of a selective laser melted nickel-base superalloy Inconel 718, Materials $\begin{array}{lllll}\text { Science } \quad \text { and } & \text { Engineering: } & 759 & \text { (2019) }\end{array}$ https://doi.org/10.1016/j.msea.2019.05.007.

[10] D. Du, A. Dong, D. Shu, G. Zhu, B. Sun, X. Li, E. Lavernia, Influence of build orientation on microstructure, mechanical and corrosion behavior of Inconel 718 processed by selective laser melting, Materials Science and Engineering: A. 760 (2019) 469-480. https://doi.org/10.1016/j.msea.2019.05.013.

[11] M. Ni, C. Chen, X. Wang, P. Wang, R. Li, X. Zhang, K. Zhou, Anisotropic tensile behavior of in situ precipitation strengthened Inconel 718 fabricated by additive manufacturing, Materials Science and Engineering: A. 701 (2017) 344-351. https://doi.org/ 10.1016/j.msea.2017.06.098.

[12] V.P. Sabelkin, G.R. Cobb, T.E. Shelton, M.N. Hartsfield, D.J. Newell, R.P. O'Hara, R.A. Kemnitz, Mitigation of anisotropic fatigue in nickel alloy 718 manufactured via selective laser melting, Materials \& Design. $182 \quad$ (2019) 108095. https://doi.org/10.1016/j.matdes.2019.108095. 
[13] L. Cordova, M. Campos, T. Tinga, Revealing the Effects of Powder Reuse for Selective Laser Melting by Powder Characterization, JOM. 71 (2019) 1062-1072. https://doi.org/10.1007/s11837-018-3305-2.

[14] L.C. Ardila, F. Garciandia, J.B. González-Díaz, P. Álvarez, A. Echeverria, M.M. Petite, R. Deffley, J. Ochoa, Effect of IN718 Recycled Powder Reuse on Properties of Parts Manufactured by Means of Selective Laser Melting, Physics Procedia. 56 (2014) 99_ 107. https://doi.org/10.1016/j.phpro.2014.08.152.

[15] M.J. Heiden, L.A. Deibler, J.M. Rodelas, J.R. Koepke, D.J. Tung, D.J. Saiz, B.H. Jared, Evolution of $316 \mathrm{~L}$ stainless steel feedstock due to laser powder bed fusion process, Additive Manufacturing. 25 (2019) 84-103. https://doi.org/10.1016/j.addma.2018.10.019.

[16] D. Powell, A. Rennie, L. Geekie, N. Burns, Understanding powder degradation in metal additive manufacturing to allow the upcycling of recycled powders, Journal of Cleaner Production. (2020) 122077. https://doi.org/10.1016/j.jclepro.2020.122077.

[17] J. Slotwinski, E. Garboczi, P. Stutzman, C. Ferraris, S. Watson, M. Peltz, Characterization of Metal Powders Used for Additive Manufacturing, J Res Natl Inst Stand Technol. 119 (2014) 460-493. https://doi.org/10.6028/jres.119.018.

[18] E. Santecchia, S. Spigarelli, M. Cabibbo, Material Reuse in Laser Powder Bed Fusion: Side Effects of the Laser-Metal Powder Interaction, Metals. 10 (2020) 341. https://doi.org/10.3390/met10030341.

[19] B.A. Hann, Powder Reuse and Its Effects on Laser Based Powder Fusion Additive Manufactured Alloy 718, SAE Int. J. Aerosp. 9 (2016) 209-213. https://doi.org/10.4271/2016-01-2071.

[20] O.A. Quintana, J. Alvarez, R. Mcmillan, W. Tong, C. Tomonto, Effects of Reusing Ti-6Al-4V Powder in a Selective Laser Melting Additive System Operated in an Industrial Setting, JOM. 70 (2018) 1863-1869. https://doi.org/10.1007/s11837-018-3011-0.

[21] H.P. Tang, M. Qian, N. Liu, X.Z. Zhang, G.Y. Yang, J. Wang, Effect of Powder Reuse Times on Additive Manufacturing of Ti-6Al-4V by Selective Electron Beam Melting, JOM. 67 (2015) 555-563. https://doi.org/10.1007/s11837-015-1300-4.

[22] H. Asgari, C. Baxter, K. Hosseinkhani, M. Mohammadi, On microstructure and mechanical properties of additively manufactured AISi10Mg_200C using recycled powder, Materials Science and Engineering: A. $707 \quad$ (2017) 148-158. https://doi.org/10.1016/j.msea.2017.09.041.

[23] F. Del Re, V. Contaldi, A. Astarita, B. Palumbo, A. Squillace, P. Corrado, P. Di Petta, Statistical approach for assessing the effect of powder reuse on the final quality of 
AISi10Mg parts produced by laser powder bed fusion additive manufacturing, Int J Adv Manuf Technol. 97 (2018) 2231-2240. https://doi.org/10.1007/s00170-018-2090-y.

[24] P.E. Carrion, A. Soltani-Tehrani, N. Phan, N. Shamsaei, Powder Recycling Effects on the Tensile and Fatigue Behavior of Additively Manufactured Ti-6Al-4V Parts, JOM. 71 (2019) 963-973. https://doi.org/10.1007/s11837-018-3248-7.

[25] Lucy Grainger, Renishaw Ti6Al4V metal powder re-use study, (2016). https://www.slideshare.net/LucyGrainger2/renishaw-ti6al4v-metal-powder-reuse-study (accessed September 29, 2020).

[26] V. Seyda, N. Kaufmann, C. Emmelmann, Investigation of Aging Processes of Ti6Al-4 V Powder Material in Laser Melting, Physics Procedia. 39 (2012) 425-431. https://doi.org/10.1016/j.phpro.2012.10.057.

[27] Y. Liu, Y. Yang, S. Mai, D. Wang, C. Song, Investigation into spatter behavior during selective laser melting of AISI 316L stainless steel powder, Materials \& Design. 87 (2015) 797-806. https://doi.org/10.1016/j.matdes.2015.08.086.

[28] A. Hilaire, E. Andrieu, X. Wu, High-temperature mechanical properties of alloy 718 produced by laser powder bed fusion with different processing parameters, Additive Manufacturing. 26 (2019) 147-160. https://doi.org/10.1016/j.addma.2019.01.012.

[29] S. Holland, X. Wang, J. Chen, W. Cai, F. Yan, L. Li, Multiscale characterization of microstructures and mechanical properties of Inconel 718 fabricated by selective laser melting, Journal of Alloys and Compounds. $784 \quad$ (2019) 182-194. https://doi.org/10.1016/j.jallcom.2018.12.380.

[30] Q. Jia, D. Gu, Selective laser melting additive manufacturing of Inconel 718 superalloy parts: Densification, microstructure and properties, Journal of Alloys and Compounds. 585 (2014) 713-721. https://doi.org/10.1016/j.jallcom.2013.09.171.

[31] J.P. Collier, S.H. Wong, J.K. Tien, J.C. Phillips, The effect of varying Al, Ti,and Nb content on the phase stability of Inconel 718, Metall Mater Trans A. 19 (1988) 1657-1666. https://doi.org/10.1007/BF02645133.

[32] S.H. Fu, J.X. Dong, M.C. Zhang, X.S. Xie, Alloy design and development of INCONEL718 type alloy, Materials Science and Engineering: A. 499 (2009) 215-220. https://doi.org/10.1016/j.msea.2007.11.115.

[33] Q.B. Nguyen, M.L.S. Nai, Z. Zhu, C.-N. Sun, J. Wei, W. Zhou, Characteristics of Inconel Powders for Powder-Bed Additive Manufacturing, Engineering. 3 (2017) 695-700. https://doi.org/10.1016/J.ENG.2017.05.012.

[34] F. Yi, Q. Zhou, C. Wang, Z. Yan, B. Liu, Effect of powder reuse on powder characteristics and properties of Inconel 718 parts produced by selective laser melting, 
Journal of Materials Research and Technology. 13 (2021) 524-533. https://doi.org/10.1016/j.jmrt.2021.04.091.

[35] G. Jacob, C.U. Brown, M.A. Donmez, S.S. Watson, Effects of powder recycling on stainless steel powder and built material properties in metal powder bed fusion processes, (2017). https://www.nist.gov/publications/effects-powder-recycling-stainless-steel-powderand-built-material-properties-metal (accessed June 4, 2021).

[36] A.T. Sutton, C.S. Kriewall, S. Karnati, M.C. Leu, J.W. Newkirk, Characterization of AISI 304L stainless steel powder recycled in the laser powder-bed fusion process, Additive Manufacturing. 32 (2020) 100981. https://doi.org/10.1016/j.addma.2019.100981.

[37] E. Hosseini, V.A. Popovich, A review of mechanical properties of additively manufactured Inconel 718, Additive Manufacturing. $30 \quad$ (2019) 100877. https://doi.org/10.1016/j.addma.2019.100877.

[38] D.G. McCartney, J.D. Hunt, Measurements of cell and primary dendrite arm spacings in directionally solidified aluminium alloys, Acta Metallurgica. 29 (1981) 18511863. https://doi.org/10.1016/0001-6160(81)90111-5.

[39] C.A. Schneider, W.S. Rasband, K.W. Eliceiri, NIH Image to ImageJ: 25 years of image analysis, Nature Methods. 9 (2012) 671-675. https://doi.org/10.1038/nmeth.2089.

[40] A. Pancou, E. Andrieu, A. Votié, Oxidation-Assisted Cracking at $650{ }^{\circ} \mathrm{C}$ in Superalloy 718 Manufactured by Laser Beam Melting: Effect of Temperature and Strain Rate, in: E. Ott, X. Liu, J. Andersson, Z. Bi, K. Bockenstedt, I. Dempster, J. Groh, K. Heck, P. Jablonski, M. Kaplan, D. Nagahama, C. Sudbrack (Eds.), Proceedings of the 9th International Symposium on Superalloy 718 \& Derivatives: Energy, Aerospace, and Industrial Applications, Springer International Publishing, 2018: pp. 711-733.

[41] H.L. Wei, G.L. Knapp, T. Mukherjee, T. DebRoy, Three-dimensional grain growth during multi-layer printing of a nickel-based alloy Inconel 718, Additive Manufacturing. 25 (2019) 448-459. https://doi.org/10.1016/j.addma.2018.11.028.

[42] N. Nadammal, S. Cabeza, T. Mishurova, T. Thiede, A. Kromm, C. Seyfert, L. Farahbod, C. Haberland, J.A. Schneider, P.D. Portella, G. Bruno, Effect of hatch length on the development of microstructure, texture and residual stresses in selective laser melted superalloy Inconel 718, Materials \& Design. 134 (2017) 139-150. https://doi.org/10.1016/j.matdes.2017.08.049.

[43] V.A. Popovich, E.V. Borisov, A.A. Popovich, V.Sh. Sufiiarov, D.V. Masaylo, L. Alzina, Functionally graded Inconel 718 processed by additive manufacturing: Crystallographic texture, anisotropy of microstructure and mechanical properties, Materials \& Design. 114 (2017) 441-449. https://doi.org/10.1016/j.matdes.2016.10.075. 
[44] C. Guévenoux, S. Hallais, Y. Balit, A. Charles, E. Charkaluk, A. Constantinescu, Plastic strain localization induced by microstructural gradient in laser cladding repaired structures, Theoretical and Applied Fracture Mechanics. (2020) 102520. https://doi.org/10.1016/j.tafmec.2020.102520.

[45] X. Wang, K. Chou, The effects of stress relieving heat treatment on the microstructure and residual stress of Inconel 718 fabricated by laser metal powder bed fusion additive manufacturing process, Journal of Manufacturing Processes. 48 (2019) 154-163. https://doi.org/10.1016/j.jmapro.2019.10.027.

[46] M.E. Aydinöz, F. Brenne, M. Schaper, C. Schaak, W. Tillmann, J. Nellesen, T. Niendorf, On the microstructural and mechanical properties of post-treated additively manufactured Inconel 718 superalloy under quasi-static and cyclic loading, Materials $\begin{array}{lllll}\text { Science } \quad \text { and } & \text { Engineering: } & 669 & \text { (2016) }\end{array}$ https://doi.org/10.1016/j.msea.2016.05.089.

[47] A. Ariaseta, S. Kobayashi, M. Takeyama, Y. Wang, S. Imano, Characterization of Recrystallization and Second-Phase Particles in Solution-Treated Additively Manufactured Alloy 718, Metall and Mat Trans A. 51 (2020) 973-981. https://doi.org/10.1007/s11661019-05560-y.

[48] M. Ni, S. Liu, C. Chen, R. Li, X. Zhang, K. Zhou, Effect of heat treatment on the microstructural evolution of a precipitation-hardened superalloy produced by selective laser melting, Materials Science and Engineering: A. 748 (2019) 275-285. https://doi.org/10.1016/j.msea.2019.01.109.

[49] H.-Y. Wan, Z.-J. Zhou, C.-P. Li, G.-F. Chen, G.-P. Zhang, Enhancing Fatigue Strength of Selective Laser Melting-Fabricated Inconel 718 by Tailoring Heat Treatment $\begin{array}{llllll}\text { Route, } & \text { Advanced } & \text { Engineering } & \text { Materials. } & 20 & \text { (2018) }\end{array}$ https://doi.org/10.1002/adem.201800307.

[50] P. Pant, S. Proper, V. Luzin, S. Sjöström, K. Simonsson, J. Moverare, S. Hosseini, V. Pacheco, R.L. Peng, Mapping of residual stresses in as-built Inconel 718 fabricated by laser powder bed fusion: A neutron diffraction study of build orientation influence on residual stresses, Additive Manufacturing. $36 \quad$ (2020) 101501. https://doi.org/10.1016/j.addma.2020.101501.

[51] S. Suresh, Fatigue of Materials, 2nd ed., Cambridge University Press, Cambridge, 1998. https://doi.org/10.1017/CBO9780511806575.

[52] K. Solberg, F. Berto, What is going on with fatigue of additively manufactured metals?, Material Design \& Processing Communications. 1 (2019) e84. https://doi.org/10.1002/mdp2.84. 
[2] M.G. Rashed, M. Ashraf, R.A.W. Mines, P.J. Hazell, Metallic microlattice materials: A current state of the art on manufacturing, mechanical properties and applications, Materials \& Design. $95 \quad$ (2016) 518-533. https://doi.org/10.1016/j.matdes.2016.01.146.

[3] I. Yadroitsev, Ph. Bertrand, I. Smurov, Parametric analysis of the selective laser melting process, Applied Surface Science. $253 \quad$ (2007) 8064-8069. https://doi.org/10.1016/j.apsusc.2007.02.088.

[4] C.Y. Yap, C.K. Chua, Z.L. Dong, Z.H. Liu, D.Q. Zhang, L.E. Loh, S.L. Sing, Review of selective laser melting: Materials and applications, Applied Physics Reviews. 2 (2015) 041101. https://doi.org/10.1063/1.4935926.

[5] K.N. Amato, S.M. Gaytan, L.E. Murr, E. Martinez, P.W. Shindo, J. Hernandez, S. Collins, F. Medina, Microstructures and mechanical behavior of Inconel 718 fabricated by selective laser melting, Acta Materialia. $60 \quad$ (2012) 2229-2239. https://doi.org/10.1016/j.actamat.2011.12.032.

[6] J. Kruth, P. Mercelis, J. Van Vaerenbergh, L. Froyen, M. Rombouts, Binding mechanisms in selective laser sintering and selective laser melting, Rapid Prototyping Journal. 11 (2005) 26-36. https://doi.org/10.1108/13552540510573365.

[7] C. Zhao, K. Fezzaa, R.W. Cunningham, H. Wen, F.D. Carlo, L. Chen, A.D. Rollett, T. Sun, Real-time monitoring of laser powder bed fusion process using high-speed X-ray imaging and diffraction, Sci Rep. 7 (2017) 1-11. https://doi.org/10.1038/s41598-01703761-2.

[8] K. Moussaoui, W. Rubio, M. Mousseigne, T. Sultan, F. Rezai, Effects of Selective Laser Melting additive manufacturing parameters of Inconel 718 on porosity, microstructure and mechanical properties, Materials Science and Engineering: A. 735 (2018) 182-190. https://doi.org/10.1016/j.msea.2018.08.037.

[9] C. Pei, D. Shi, H. Yuan, H. Li, Assessment of mechanical properties and fatigue performance of a selective laser melted nickel-base superalloy Inconel 718, Materials $\begin{array}{lllll}\text { Science } \quad \text { and } & \text { Engineering: } & 759 & \text { (2019) }\end{array}$ https://doi.org/10.1016/j.msea.2019.05.007.

[10] D. Du, A. Dong, D. Shu, G. Zhu, B. Sun, X. Li, E. Lavernia, Influence of build orientation on microstructure, mechanical and corrosion behavior of Inconel 718 processed by selective laser melting, Materials Science and Engineering: A. 760 (2019) 469-480. https://doi.org/10.1016/j.msea.2019.05.013. 
[11] M. Ni, C. Chen, X. Wang, P. Wang, R. Li, X. Zhang, K. Zhou, Anisotropic tensile behavior of in situ precipitation strengthened Inconel 718 fabricated by additive manufacturing, Materials Science and Engineering: A. 701 (2017) 344-351. https://doi.org/ 10.1016/j.msea.2017.06.098.

[12] V.P. Sabelkin, G.R. Cobb, T.E. Shelton, M.N. Hartsfield, D.J. Newell, R.P. O'Hara, R.A. Kemnitz, Mitigation of anisotropic fatigue in nickel alloy 718 manufactured via selective laser melting, Materials \& Design. $182 \quad$ (2019) 108095. https://doi.org/10.1016/j.matdes.2019.108095.

[13] L. Cordova, M. Campos, T. Tinga, Revealing the Effects of Powder Reuse for Selective Laser Melting by Powder Characterization, JOM. 71 (2019) 1062-1072. https://doi.org/10.1007/s11837-018-3305-2.

[14] L.C. Ardila, F. Garciandia, J.B. González-Díaz, P. Álvarez, A. Echeverria, M.M. Petite, R. Deffley, J. Ochoa, Effect of IN718 Recycled Powder Reuse on Properties of Parts Manufactured by Means of Selective Laser Melting, Physics Procedia. 56 (2014) 99_ 107. https://doi.org/10.1016/j.phpro.2014.08.152.

[15] M.J. Heiden, L.A. Deibler, J.M. Rodelas, J.R. Koepke, D.J. Tung, D.J. Saiz, B.H. Jared, Evolution of 316L stainless steel feedstock due to laser powder bed fusion process, Additive Manufacturing. 25 (2019) 84-103. https://doi.org/10.1016/j.addma.2018.10.019.

[16] D. Powell, A. Rennie, L. Geekie, N. Burns, Understanding powder degradation in metal additive manufacturing to allow the upcycling of recycled powders, Journal of Cleaner Production. (2020) 122077. https://doi.org/10.1016/j.jclepro.2020.122077.

[17] J. Slotwinski, E. Garboczi, P. Stutzman, C. Ferraris, S. Watson, M. Peltz, Characterization of Metal Powders Used for Additive Manufacturing, J Res Natl Inst Stand Technol. 119 (2014) 460-493. https://doi.org/10.6028/jres.119.018.

[18] B.A. Hann, Powder Reuse and Its Effects on Laser Based Powder Fusion Additive Manufactured Alloy 718, SAE Int. J. Aerosp. 9 (2016) 209-213. https://doi.org/10.4271/2016-01-2071.

[19] O.A. Quintana, J. Alvarez, R. Mcmillan, W. Tong, C. Tomonto, Effects of Reusing Ti-6Al-4V Powder in a Selective Laser Melting Additive System Operated in an Industrial Setting, JOM. 70 (2018) 1863-1869. https://doi.org/10.1007/s11837-018-3011-0.

[20] H.P. Tang, M. Qian, N. Liu, X.Z. Zhang, G.Y. Yang, J. Wang, Effect of Powder Reuse Times on Additive Manufacturing of Ti-6Al-4V by Selective Electron Beam Melting, JOM. 67 (2015) 555-563. https://doi.org/10.1007/s11837-015-1300-4.

[21] H. Asgari, C. Baxter, K. Hosseinkhani, M. Mohammadi, On microstructure and mechanical properties of additively manufactured AISi10Mg_200C using recycled powder, 
Materials Science and Engineering: A. $707 \quad$ (2017) 148-158. https://doi.org/10.1016/j.msea.2017.09.041.

[22] F. Del Re, V. Contaldi, A. Astarita, B. Palumbo, A. Squillace, P. Corrado, P. Di Petta, Statistical approach for assessing the effect of powder reuse on the final quality of AISi10Mg parts produced by laser powder bed fusion additive manufacturing, Int J Adv Manuf Technol. 97 (2018) 2231-2240. https://doi.org/10.1007/s00170-018-2090-y.

[23] P.E. Carrion, A. Soltani-Tehrani, N. Phan, N. Shamsaei, Powder Recycling Effects on the Tensile and Fatigue Behavior of Additively Manufactured Ti-6Al-4V Parts, JOM. 71 (2019) 963-973. https://doi.org/10.1007/s11837-018-3248-7.

[24] Lucy Grainger, Renishaw Ti6Al4V metal powder reuse study, (2016). https://www.slideshare.net/LucyGrainger2/renishaw-ti6al4v-metal-powder-reuse-study (accessed September 29, 2020).

[25] V. Seyda, N. Kaufmann, C. Emmelmann, Investigation of Aging Processes of Ti6Al-4 V Powder Material in Laser Melting, Physics Procedia. 39 (2012) 425-431. https://doi.org/10.1016/j.phpro.2012.10.057.

[26] Y. Liu, Y. Yang, S. Mai, D. Wang, C. Song, Investigation into spatter behavior during selective laser melting of AISI 316L stainless steel powder, Materials \& Design. 87 (2015) 797-806. https://doi.org/10.1016/j.matdes.2015.08.086.

[27] A. Hilaire, E. Andrieu, X. Wu, High-temperature mechanical properties of alloy 718 produced by laser powder bed fusion with different processing parameters, Additive Manufacturing. 26 (2019) 147-160. https://doi.org/10.1016/j.addma.2019.01.012.

[28] S. Holland, X. Wang, J. Chen, W. Cai, F. Yan, L. Li, Multiscale characterization of microstructures and mechanical properties of Inconel 718 fabricated by selective laser melting, Journal of Alloys and Compounds. $784 \quad$ (2019) 182-194. https://doi.org/10.1016/j.jallcom.2018.12.380.

[29] Q. Jia, D. Gu, Selective laser melting additive manufacturing of Inconel 718 superalloy parts: Densification, microstructure and properties, Journal of Alloys and Compounds. 585 (2014) 713-721. https://doi.org/10.1016/j.jallcom.2013.09.171.

[30] E. Hosseini, V.A. Popovich, A review of mechanical properties of additively manufactured Inconel 718, Additive Manufacturing. $30 \quad$ (2019) 100877. https://doi.org/10.1016/j.addma.2019.100877.

[31] D.G. McCartney, J.D. Hunt, Measurements of cell and primary dendrite arm spacings in directionally solidified aluminium alloys, Acta Metallurgica. 29 (1981) 18511863. https://doi.org/10.1016/0001-6160(81)90111-5. 
[32] C.A. Schneider, W.S. Rasband, K.W. Eliceiri, NIH Image to ImageJ: 25 years of image analysis, Nature Methods. 9 (2012) 671-675. https://doi.org/10.1038/nmeth.2089.

[33] A. Pancou, E. Andrieu, A. Votié, Oxidation-Assisted Cracking at $650{ }^{\circ} \mathrm{C}$ in Superalloy 718 Manufactured by Laser Beam Melting: Effect of Temperature and Strain Rate, in: E. Ott, X. Liu, J. Andersson, Z. Bi, K. Bockenstedt, I. Dempster, J. Groh, K. Heck, P. Jablonski, M. Kaplan, D. Nagahama, C. Sudbrack (Eds.), Proceedings of the 9th International Symposium on Superalloy 718 \& Derivatives: Energy, Aerospace, and Industrial Applications, Springer International Publishing, 2018: pp. 711-733.

[34] H.L. Wei, G.L. Knapp, T. Mukherjee, T. DebRoy, Three-dimensional grain growth during multi-layer printing of a nickel-based alloy Inconel 718, Additive Manufacturing. 25 (2019) 448-459. https://doi.org/10.1016/j.addma.2018.11.028.

[35] N. Nadammal, S. Cabeza, T. Mishurova, T. Thiede, A. Kromm, C. Seyfert, L. Farahbod, C. Haberland, J.A. Schneider, P.D. Portella, G. Bruno, Effect of hatch length on the development of microstructure, texture and residual stresses in selective laser melted superalloy Inconel 718, Materials \& Design. $134 \quad$ (2017) 139-150. https://doi.org/10.1016/j.matdes.2017.08.049.

[36] V.A. Popovich, E.V. Borisov, A.A. Popovich, V.Sh. Sufiiarov, D.V. Masaylo, L. Alzina, Functionally graded Inconel 718 processed by additive manufacturing: Crystallographic texture, anisotropy of microstructure and mechanical properties, Materials \& Design. 114 (2017) 441-449. https://doi.org/10.1016/j.matdes.2016.10.075.

[37] C. Guévenoux, S. Hallais, Y. Balit, A. Charles, E. Charkaluk, A. Constantinescu, Plastic strain localization induced by microstructural gradient in laser cladding repaired structures, Theoretical and Applied Fracture Mechanics. (2020) 102520. https://doi.org/10.1016/j.tafmec.2020.102520.

[38] X. Wang, K. Chou, The effects of stress relieving heat treatment on the microstructure and residual stress of Inconel 718 fabricated by laser metal powder bed fusion additive manufacturing process, Journal of Manufacturing Processes. 48 (2019) 154-163. https://doi.org/10.1016/j.jmapro.2019.10.027.

[39] M.E. Aydinöz, F. Brenne, M. Schaper, C. Schaak, W. Tillmann, J. Nellesen, T. Niendorf, On the microstructural and mechanical properties of post-treated additively manufactured Inconel 718 superalloy under quasi-static and cyclic loading, Materials $\begin{array}{llll}\text { Science and } \quad \text { Engineering: } & 669 \quad \text { (2016) }\end{array}$ https://doi.org/10.1016/j.msea.2016.05.089.

[40] A. Ariaseta, S. Kobayashi, M. Takeyama, Y. Wang, S. Imano, Characterization of Recrystallization and Second-Phase Particles in Solution-Treated Additively Manufactured 
Alloy 718, Metall and Mat Trans A. 51 (2020) 973-981. https://doi.org/10.1007/s11661019-05560-y.

[41] M. Ni, S. Liu, C. Chen, R. Li, X. Zhang, K. Zhou, Effect of heat treatment on the microstructural evolution of a precipitation-hardened superalloy produced by selective laser melting, Materials Science and Engineering: A. 748 (2019) 275-285. https://doi.org/10.1016/j.msea.2019.01.109.

[42] H.-Y. Wan, Z.-J. Zhou, C.-P. Li, G.-F. Chen, G.-P. Zhang, Enhancing Fatigue Strength of Selective Laser Melting-Fabricated Inconel 718 by Tailoring Heat Treatment $\begin{array}{llllll}\text { Route, } & \text { Advanced } & \text { Engineering } & \text { Materials. } & 20 & \text { (2018) }\end{array}$ https://doi.org/10.1002/adem.201800307.

[43] P. Pant, S. Proper, V. Luzin, S. Sjöström, K. Simonsson, J. Moverare, S. Hosseini, V. Pacheco, R.L. Peng, Mapping of residual stresses in as-built Inconel 718 fabricated by laser powder bed fusion: A neutron diffraction study of build orientation influence on $\begin{array}{lllll}\text { residual stresses, } & \text { Additive } & \text { Manufacturing. } & 36 & \text { (2020) }\end{array}$ https://doi.org/10.1016/j.addma.2020.101501.

[44] S. Suresh, Fatigue of Materials, 2nd ed., Cambridge University Press, Cambridge, 1998. https://doi.org/10.1017/CBO9780511806575.

[45] K. Solberg, F. Berto, What is going on with fatigue of additively manufactured metals?, Material Design \& Processing Communications. 1 (2019) e84. https://doi.org/10.1002/mdp2.84. 